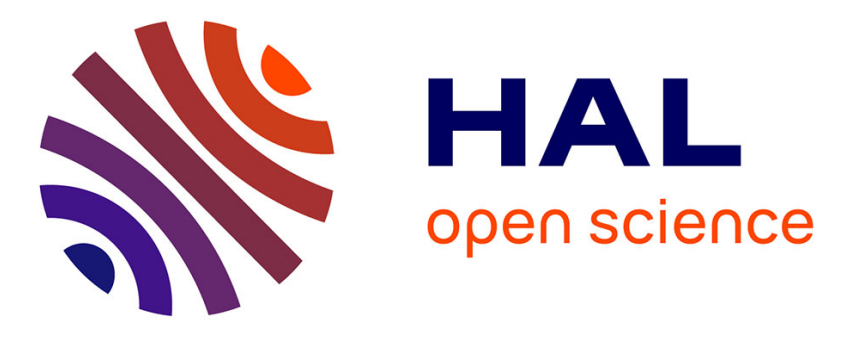

\title{
Decision-making criteria for plant-species selection for phytostabilization: Issues of biodiversity and functionality
}

Ahlem Ellili, Jacques Rabier, Pascale Prudent, Marie-Dominique Salducci, Alma Heckenroth, Mokhtar Lachaâl, Isabelle Laffont-Schwob

\section{To cite this version:}

Ahlem Ellili, Jacques Rabier, Pascale Prudent, Marie-Dominique Salducci, Alma Heckenroth, et al.. Decision-making criteria for plant-species selection for phytostabilization: Issues of biodiversity and functionality. Journal of Environmental Management, 2017, 201, pp.215-226. 10.1016/j.jenvman.2017.06.041 . hal-01577956

\section{HAL Id: hal-01577956 \\ https://hal-amu.archives-ouvertes.fr/hal-01577956}

Submitted on 14 May 2018

HAL is a multi-disciplinary open access archive for the deposit and dissemination of scientific research documents, whether they are published or not. The documents may come from teaching and research institutions in France or abroad, or from public or private research centers.
L'archive ouverte pluridisciplinaire HAL, est destinée au dépôt et à la diffusion de documents scientifiques de niveau recherche, publiés ou non, émanant des établissements d'enseignement et de recherche français ou étrangers, des laboratoires publics ou privés. 
1

1

2

3

4

5

6

7

8

9

3

4

5

6

7

8

9 10

\section{Decision-making criteria for plant-species selection for phytostabilization: issues of} biodiversity and functionality

\section{Abstract}

Ahlem Ellili ${ }^{1,2}$, Jacques Rabier ${ }^{1}$, Pascale Prudent ${ }^{3}$, Marie-Dominique Salducci ${ }^{1}$, Alma Heckenroth $^{1}$, Mokhtar Lachaâl ${ }^{2}$, Isabelle Laffont-Schwob ${ }^{{ }^{*}}$

1 Aix Marseille Univ, Avignon Université, CNRS, IRD, IMBE, Marseille, France. (ahlem.ellili@gmail.com, jacques.rabier@imbe.fr, marie-dominique.salducci@imbe.fr, alma.heckenroth@imbe.fr, isabelle.schwob@univ-amu.fr)

${ }^{2}$ Faculty of Sciences of Tunis, Physiology and Biochemistry of Plant Response to Abiotic Stresses Unit, University of Tunis El Manar, 1060, Tunis El Manar, Campus Universitaire Farhat Hached B.P. N $N^{\circ} 94$ - Rommana 1068, Tunisia (ahlem.ellili@gmail.com, mokhtar.lachaal@fst.rnu.tn)

${ }^{3}$ Aix Marseille Univ, CNRS, LCE, Marseille, France. (pascale.prudent@univ-amu.fr)

* Corresponding author

Isabelle Laffont-Schwob

Aix Marseille Univ, Avignon Université, CNRS, IRD, IMBE, 3 place Victor Hugo, case 4, 13331 Marseille cedex 3, France

Phone:+33 (0)4 135512 30, Email: isabelle.schwob@univ-amu.fr 
In polluted protected areas, using phytoremediation raises the question of the choice of the plant species to select. As an example, Atriplex halimus has been identified as a proliferative plant species that needs to be eradicated in the Calanques National Park (PNCal). Since it has been proven that the spontaneous populations of this plant species could phytostabilize shore waste deposits generated by past industrial activities within the PNCal territory, its status seems controversial, presenting a dilemma between biodiversity management of a protected area and ecological solutions for pollution management. To address this issue, we assessed the ability of $A$. halimus to grow on different soils from this territory, in order to estimate the potential invasiveness of this plant in this territory. Petri dish germinations and pot-growth experiments showed $50 \%$ germination of seeds collected on local individuals from the most polluted PNCal soil and 20\% growth reduction of seedlings. Soil analysis showed that limitation of growth was caused by high $\mathrm{pH}$ value and sparsely available micronutrients as well as metal and metalloid contamination. Our results suggested that local populations of $A$. halimus may stabilize the highly metal and metalloid polluted salt-affected soils of the PNCal, with low seed germination potential lowering the eventuality of a propagation over the PNCal territory. As a consequence of this study, the administration of the PNCal decided not to remove $A$. halimus populations along the polluted coastline until another solution to prevent pollution dispersal had been found. This laboratory approach may be extended to other similar situations where plant species may be evaluated not only in term of phytoremediation potential but also in term of biodiversity preservation.

Keywords: Atriplex halimus, ecological management, metals and metalloids, phytostabilization, potential invasiveness. 


\section{Introduction}

Problem statement

4

Most of the papers dealing with in-situ soil phytoremediation examine persistence of selected agronomic plant species in polluted sites and mainly use efficiency of the pollution management as the major criteria of success (Vangrosveld et al., 2009; Kidd et al., 2015). Apart from this mainstream approach, the use in phytoremediation of native plants to avoid introduction of non-native and potentially invasive species that may result in decreasing regional plant diversity has been discussed (Mendez and Maier, 2008) and pilot assays using local plant assemblages for phytostabilization in polluted protected areas have been incremented (Heckenroth et al., 2016). However in certain cases, the status of invasiveness or even more of indigeneity is still controversial for some plant species and new criteria of evaluation of the compliance of these plants for phytoremediation of protected polluted areas have to be investigated. Moreover, although the great majority of invasive species are introduced, occasionally native plant species may become invasive, spreading rapidly into previously unoccupied habitats according to Simberloff (2011), these new habitats may correspond to recently polluted habitats. In France, many national parks host polluted soils in their territory (Desrousseaux and Ugo, 2016) and worldwide this situation occurs regularly (Mazurek et al., 2017; Armendáriz-Villegas et al. 2015). Amongst invasive plant species, some of them are really good candidates for phytoremediation such as Miscanthus X giganteus or alimurgic species (Bandiera et al., 2016). However, in protected areas, phytoremediation approach favour phytostabilization i.e. use of plant cover to reduce pollutant mobility in soils rather than phytoextraction i.e. use of the ability of some plants for metal translocation in their aerial parts involving the removal of the aerial parts. Thus, determining the benefit of ecological services vs the proliferation risk of these controversial plant species in polluted protected areas is important to assess and also better understanding 
the local parameters and specially soil characteristics that enable or not their proliferation and their ability for metal phytostabilization.

Atriplex halimus: example of a controversial species in a protected area

To illustrate this situation, the plant species Atriplex halimus (Amaranthaceae), a xerohalophyte that mainly grows in salt-affected nitrophilous and/or degraded soils with a high tolerance to drought (Walker et al., 2014), may be an expressive case study in the Mediterranean area. This plant species has a high tolerance to metal and metalloid elements (MM) and numerous papers dealing with its potential use for phytoremediation have recently been published, showing the growing interest in this plant species (Caçador and Duarte, 2015; El-Bakatoushi et al., 2015; Manousaki and Kalogerakis, 2009; Márquez-García et al., 2013; Pardo et al., 2014; Pérez-Esteban et al., 2013; see reviews by Lutts and Lefèvre, 2015; Walker et al., 2014). Atriplex halimus has been widely cultivated as forage or wind barrier in much of the world (Otal et al., 2010; Walker et al., 2014), although it originated in the Mediterranean Basin (Ortíz-Dorda et al., 2005; Walker et al., 2014). In South East France (Mediterranean coast), spontaneous populations of A. halimus are found in polluted coastal soils of a protected area i.e. the Calanques National Park (PNCal). Though part of the populations present on the site may be native of Ibero-Provençal origin, according to Ortíz-Dorda et al. (2005), the Mediterranean National Botanical Conservatory (MNBC), a French authority for plant conservation, considers that many ornamental individuals of this species planted as hedges near housing might have escaped from neighbouring gardens and originated most of the populations currently occurring along the coast of the PNCal on the basis of phytosociological criteria. Therefore the MNBC suggested the eradication of A. halimus from the territory of the PNCal in the same way as the notorious invasive species Carpobrotus edulis in Mediterranean (Affre et al., 2010). However, the composition of the soil near the coastal road in the PNCal was definitely altered by slag deposits from past industrial activities 
95 from the 19th to the mid-20th century (Laffont-Schwob et al., 2011; Daumalin and Laffont-

96 Schwob, 2016), and it has been demonstrated that stands of spontaneous A. halimus 97 phytostabilize these polluted soils, preventing soil erosion, diffuse pollution and 98 contamination of the food web (Rabier et al., 2014).

This turns to a cornelian dilemma for the PNCal between plant conservation including invasive plant eradication and maintaining pollution management to prevent pollutant transfer to terrestrial and sea biocoenosis. Therefore, a set of effective parameters has been examined to provide decisional criteria for the PNCal.

\section{Methodological approach}

A genetic approach for the study of the PNCal A. halimus populations would be too expensive, time-consuming and probably not effective for determining the autochthonous status or not of these populations. In addition to showing high genetic variability (Abbad et al. 2004; Ortíz-Dorda et al. 2005), local populations may have been subject to microevolution processes due to the driving force of high MM pollution, as has been recently proven for another pseudo-metallophyte (Słomka et al., 2011).

An ecological approach on life traits may be more accurate to evaluate the potential of invasiveness of this species on a specific territory. A. halimus mainly spreads via seeds that may be transported by animals, air or water and, to a lesser extent, can propagate vegetatively (Walker et al., 2014). A potential spread of this species at the expense of other native plant species, especially rare ones, needs to be taken into account. Therefore the invasiveness potential may be evaluated as the ability of this species to germinate and grow in soil conditions differing from those in which its currently develop. While the tolerance of $A$. halimus to MM in coastal areas has been demonstrated previously on older in situ individuals, no information is available on its capacity to establish on the more or less polluted soils of 
this territory. More scientific information on the ecological preferendum of $A$. halimus is thus necessary. As a first step, the ability of local A. halimus populations to germinate and grow on various soils from the PNCal territory needs to be assessed. Therefore, an ex-situ experiment was conducted in laboratory on the germination, seedling growth and MM accumulation capacities and on chemical and ecological traits of $A$. halimus in various PNCal soils. The results are discussed in a global perspective to propose a methodological approach for the selection or keep up of non-native or potentially invasive plant species in polluted protected areas.

\section{Materials and methods}

\subsection{Study area and soil sampling}

130 The current PNCal territory was the site of metallurgical and chemical industrial activities 131 from the mid-19th century until the beginning of the 20th century. Silver-galena ore was

treated by pyrometallurgical processes during this period (Daumalin and Raveux, 2016). The former Escalette factory (in operation from 1851 to 1924) was the one that had the most intensive activity in the area. The factory, located on the lower slopes of a hill, was characterized by a horizontal smelter chimney as the condensing system. The ruins of this chimney are still present today. In well-constructed flues, the deposit could yield from $2 \%$ to $3 \%$, while loss dispersed in the smoke could amount to around $10 \%$ of the lead produced in the ore, depending on its quality (Percy, 1870). Slag was deposited on the old factory site, but was also scattered along the coast in several main deposits and as roadfill. Six sites were selected for this study (supp. data 1), located in the peri-urban area of Marseille, south-east France, i.e. Calanque de Saména (SA, 43 $13.749^{\prime}$ N; $5^{\circ} 20.960^{\prime}$ E) and Calanque des Trous (TR, $\left.43^{\circ} 13.233^{\prime} \mathrm{N} ; 5^{\circ} 20.766^{\prime} \mathrm{E}\right)$, corresponding to soils from moderately polluted seashore sites where $A$. halimus grows spontaneously; Escalette Chimney (E.C, $43^{\circ} 13.584^{\prime} \mathrm{N} ; 5^{\circ} 21.32^{\prime}$ 
144 E) and Escalette Slagheap (E.S, $43^{\circ} 13.454^{\prime} \mathrm{N} ; 5^{\circ} 21.126^{\prime} \mathrm{E}$ ), corresponding to soils from the

145 former Escalette smelter heavily polluted by two different steps of the smelting process; Cap Croisette (CC, $\left.43^{\circ} 12.812^{\prime} \mathrm{N} ; 5^{\circ} 20.899^{\prime} \mathrm{E}\right)$, a site exposed to very low pollution and seaspray; Sormiou ( $\mathrm{SO}, 43^{\circ} 12.806^{\prime} \mathrm{N} ; 5^{\circ} 24.964^{\prime} \mathrm{E}$ ), a site exposed to very low pollution and no seaspray; and in order to have a reference condition, was chosen as a control substrate a loamy horticultural soil $(\mathrm{CN}$, mixture of peat moss, sphagnum peat moss, wood fiber and plant cultivation support composted with NPK 8-2-7, Botanic $\left.{ }^{\circledR}\right)$. The areas were chosen on the basis of previously published data on metal and metalloid contamination in the PNCal area (Laffont-schwob et al., 2016) and according to similar physico-chemical characteristics of the soils (except level of MM contamination). All soils are pooled samples of five subsamples collected on the top soil: for SA, TR and CC, soils are from the root zone of Atriplex populations as previously described (Rabier et al., 2014); for E.C., E.S and SO, soils samples were collected under mattoral plant cover (Testiati et al., 2013; Affholder et al., 2013).

157 On each of the six selected sites, soil samples were collected from the top $15 \mathrm{~cm}$ after removal 158 of the litter. In order to obtain representative samples of each site, a composite soil sample soil sample was stored in a plastic bag until returned to the laboratory.

162 An ex-situ assay by pot experimentation in the laboratory was conducted with these 163 composite soils, to assess the germination and growth capacities of A. halimus from seeds 164 collected on spontaneous individuals in the area on these MM and salt-affected soils. 
In the laboratory, soil composite aliquots were air-dried at room temperature and then ground 168 to pass through a $0.2 \mathrm{~mm}$ titanium sieve (RETSCH zm 1000 with tungsten blades) before 169 analyses. Physico-chemical parameters of soil, i.e. salinity, $\mathrm{pH}$, conductivity, texture, total 170 organic carbon and total Kjeldahl nitrogen content, and trace and major element 171 concentrations, were determined on 3 analytical replicates of each soil composite sample per 172 site.

173 Measurements of $\mathrm{pH}$ (ISO 10390, 2005) and salinity (calculated from conductivity) were 174 determined by potentiometry in a 1:5 soil:water suspension using a Multi 3420 SET B-WTW $175 \mathrm{pH}$ meter and ECmeter (Baize, 2000).

176 Total organic carbon (TOC) quantifications were carried out with a Jena Analytic TOC177 N/C2100S, coupled with HT1300 solid module (ISO 10694, 1995). Total Kjeldahl nitrogen 178 content was measured with Büchi 323 digester and distillation units (ISO 11261, 1995).

179 For MM analyses, soil samples were mineralized in a microwave mineralizer (Milestone Start 180 D) using aqua regia $\left(1 / 3 \mathrm{HNO}_{3}+2 / 3 \mathrm{HCl}\right)$. The solutions obtained for soil mineralization 181 were filtered with a $0.45 \mu \mathrm{m}$ mesh and the metal levels were determined by ICP-AES 182 (JobinYvon Horiba, Spectra 2000) for As, Cu, Fe, Mn, Pb, Sb and Zn (Lotmani et al., 2011); 183 flame AES (Thermo Scientific ICE 3000) was used for Na and K measurements. Cd was not 184 taken into account since results showed concentration levels far below 1ppm. Quality 185 assurance controls and accuracy were checked using standard soil reference materials (CRM 186 049-050, from RTC-USA) with accuracies within $100 \pm 10 \%$. Results are presented in supp. 187 data 2.

188 The following analyzes were performed by the Laboratoire Developpement Méditerranée at 189 Alès (Gard, France). The soil texture was measured on five non-decarbonated fractions (NF X 190 31-107, 2003), the exchangeable $\mathrm{P}\left(\mathrm{P}_{2} \mathrm{O}_{5}\right)$ was determined according to the Joret Hébert 
method (ISO 11263, 1995), the cation exchange capacity (CEC) was measured according to the Metson method (ISO 23470, 2007), extraction of the exchangeable cations was carried out with ammonium acetate (ISO 23470, 2007).

\subsection{Seed collection}

A. halimus seeds were collected in September 2013 from 5 individuals of the spontaneous 197 population at Escalette (highly polluted site, supp. data 1), then pooled and stored in paper 198 bags at room temperature until use. No information is available on this population regarding 199 its potential ornamental origin, but it was confirmed that the chromosome number of this

\subsection{Seed germination experiment}

Seeds were removed from their bracts by dragging them over sandpaper. The seeds were surface-sterilised just before use by immersion in $5 \%(\mathrm{v} / \mathrm{v})$ sodium hypochlorite for $10 \mathrm{~min}$ and rinsed three times in sterile water, a treatment that does not affect germination parameters or seedling characteristics (Muñoz-Rodríguez et al., 2012).

The seeds were germinated under controlled conditions with $12 / 12 \mathrm{~h}$ of day/night at $24 / 20{ }^{\circ} \mathrm{C}$, respectively, constant humidity $60 \%$, that have been proven to be appropriate conditions to enhance the percentage of germination in A. halimus (Muñoz-Rodríguez et al., 2012). The Petri dishes were put in a plant growth chamber (SANYO MLR-351H). The light was 
provided by fluorescent lamps that produce an average photosynthetic photon flux density of $300 \mu \mathrm{mol} / \mathrm{m}^{2} / \mathrm{s}$. Germination tests were carried out in Petri dishes filled with $40 \mathrm{ml}$ of every soil type (corresponding to $20 \mathrm{~g}$ of composite soil (sieved to $2 \mathrm{~mm}$ ) from each site and $5 \mathrm{~g}$ of control substrate $(\mathrm{CN})$, due to the different substrate densities). These different soils were watered with distilled water to near field capacity. Ten replicates of 30 seeds were used for each soil type. Germination was monitored every 2-days by counting the number of germinated seeds per Petri dish (Keiffer and Ungar, 1997). Seeds were considered to have germinated after radicle emergence.

\subsection{Growth conditions and plant morphology}

224 The six composite soils (sieved to $2 \mathrm{~mm}$ ) and the control $(\mathrm{CN})$ were distributed in individual $225120 \mathrm{ml}-$ paper pots ( $100 \mathrm{ml}$ of dried soil per pot from the six PNCal sites or $\mathrm{CN})$ in order to

Plant height (shoots) and number of leaves were measured every 7 days.

235 At the end of the experiment, the plants were carefully removed and then separated into roots, 
were rinsed with deionized water (three successive rinses of $30 \mathrm{~s}$ each), then gently blotted between paper towels. Morphological parameters (root length, shoot length, and leaf number) were measured on each plant.

Leaf surface areas were determined using a scanner and ImageJ software (URL: 241 http://rsbweb.nih.gov/ij/).

242 Shoot and root fresh weights (FW) were determined immediately. The pooled root samples 243 per pot were oven-dried at $40{ }^{\circ} \mathrm{C}$ for $48 \mathrm{~h}$ to determine the root dry weight (DW). Dry weight 244 determination was done identically from pooled shoot samples per pot.

245 Hydration rates (HR) were calculated on shoots and roots of plants grown on the different 246 soils, as described elsewhere (Rabier et al. 2007)

247 The root and shoot dry material was ground separately for metal analysis. Finally, MM 248 concentrations were analyzed in root and shoot parts.

\subsection{Non-destructive plant physiological index measurements}

251 At three different stages (35, 55 and 63 days), plant physiological indices were estimated 252 optically using a Multiplex® 3 non-destructive measurement equipment (FORCE-A, Orsay, 253 France; Agati et al., 2011). This portable fluorimetric device uses fluorescence technology 254 with multiple excitations to measure constitutive and induced epidermal phenols, flavonols, 255 anthocyanins, chlorophylls and a chlorophyll-to-flavonoid ratio referred to as nitrogen 256 balance index (NBI). Different combinations of the blue-green, red and far-red fluorescence 257 signals at the various excitation bands could be used as indices of the different compounds 258 (Agati et al., 2011; Cerovic et al., 2008). Though we used the term 'anthocyanin indices' 259 because the apparatus was developed for relative measurement of anthocyanin, the red 
pigments of $A$. halimus are betalains, as for other members of the Amaranthaceae with a similar absorbance spectrum (Lavene, 1995; LoPresti, 2015). For each type of soil, the average of five measurements was made per pot and was repeated for the 10 pot replicates. Before starting the measurement by Multiplex, we covered the soil of each pot with pieces of blackboard wall stickers to avoid fluorescence of organic matter from soil.

\subsection{Plant elemental analysis}

267 Before analysis, dried shoot and root plant samples from the 10 replicates were pooled 268 separately. They were then ground to pass a $0.2 \mathrm{~mm}$ mesh titanium sieve and three aliquots 269 were analyzed by sample. About $0.5 \mathrm{~g}$ of dry matter was digested with the microwave 270 digestion system Milestone start D with a $\mathrm{HNO}_{3}, \mathrm{H}_{2} \mathrm{O}_{2}$ and ultra-pure $\mathrm{H}_{2} \mathrm{O}$ mixture (volume 271 proportion ratio 2:1:1). Extracts were analyzed for pseudo-total metals and metalloids (MM) 272 i.e. $\mathrm{Cu}, \mathrm{Fe}, \mathrm{Mn}, \mathrm{Pb}$, and $\mathrm{Zn}$ content, using inductively coupled plasma-atomic emission 273 spectroscopy (ICP-AES, JY 2000 Jobin Yvon Horiba) and by graphite furnace AAS (Thermo 274 Scientific ICE 3000) for As and Sb, while flame AES (Thermo Scientific ICE 3000) was used 275 for $\mathrm{Na}$ and $\mathrm{K}$ measurements. Three analytical replicates were performed for each type of plant 276 sample. Standard plant reference materials (DC 73349) from China National Analysis Centre 277 for Iron and Steel (NSC) were analyzed as part of the quality control protocol (accuracies 278 within $100 \pm 10 \%$ ).

279 To evaluate the phytoremediation ability of the plants, bioaccumulation factors (BCF) and 280 translocation factors (TF) in each soil were computed according to the following formula 281 (Yoon et al., 2006):

$282 \mathrm{BCF}=\mathrm{C}_{\text {root }} / \mathrm{C}_{\text {soil }}(1)$ 
$\mathrm{TF}=\mathrm{C}_{\text {shoot }} / \mathrm{C}_{\text {root }}(2)$

284 Where $\mathrm{C}_{\text {soil }}, \mathrm{C}_{\text {root}}, \mathrm{C}_{\text {shoot }}$ are average concentrations of trace elements in soils, roots and shoots, 285 respectively. These factors indicate the importance of pollutant transfer from soils to roots $286(\mathrm{BCF})$ and from roots to shoots (TF).

287 A quantitative approach of the multi-element contamination can be made based on the 288 pollution load indices (PLI) calculated for each soil following Rashed (2010):

$289 \mathrm{PLI}=\sqrt[5]{C F_{A s} \times C F_{C u} \times C F_{P b} \times C F_{S b} \times C F_{Z n}}$

290 with $\mathrm{CF}_{\mathrm{MM}}=[\mathrm{MM}]_{\text {considered soil }} /[\mathrm{MM}]_{\mathrm{SO}}$

291 CF being the soil contamination factor and Sormiou (SO) being considered as the reference 292 area for this study since MM soil concentrations at this site are very close to the local

\subsection{Root symbiosis observations}

297 Before the final harvest, an individual from each pot was removed for root symbiosis analysis (10 replicates per soil type). The roots of these plants were rinsed first under tap then deionized water, pooled in three replicates for each soil type and stored in alcohol $(60 \%, \mathrm{v} / \mathrm{v})$ at room temperature until proceeding. To limit the use of highly toxic products, we used the method described by Vierheilig et al. (1998) for staining fungal structures before observation. First roots were soaked for $3 \mathrm{~min}$ in $10 \% \mathrm{KOH}$ bath at $80{ }^{\circ} \mathrm{C}$ then rinsed and stained with Pelikan ${ }^{\circledR}$ blue ink, in a $5 \%$ acetic acid solution at $90{ }^{\circ} \mathrm{C}$ for $3 \mathrm{~min}$. The roots were mounted on slides. For each sample, five slides were prepared, each containing 10 root fragments of 1 $\mathrm{cm}$ length. Therefore the results are based on the observation of 50 fragments of roots per 
306

1

replicate. The arbuscular mycorrhizal (AM) structures were sorted into mycelium (M), 307 vesicles (V) and arbuscular (A) structures, using optical microscopy at 100 and 400 308 magnifications.

309 The structures of dark septate endophytes (DSE) i.e. septate melanized mycelia and 310 microsclerotia were observed. The percentages of each symbiotic structure $(\mathrm{A}, \mathrm{M}, \mathrm{V}$ and 311 DSE) observed in the samples were independently estimated for each soil type, using the 312 formula of Zhang et al. (2010):

313 Percentage of fungal structures observed $=100 *$ number of fragments where the structure 314 was observed / number of observed fragments. Information about root symbioses may 315 indicate the ability of the plant to interact with edaphic micro-organisms, playing a role in 316 plant pollutant tolerance but also giving an indication of the potential occurrence of symbionts 317 in polluted soils (biological characteristic of soils).

\subsection{Statistical analysis}

320 Statistical analyses and control carts were performed for all data using JMP 11 statistical 321 software (SAS Institute, Cary, North Carolina, USA). A. halimus germination percentages, $322 \mathrm{MM}$ concentrations in plant parts and soils, plant stress indices and fungal root colonization 323 percentages were compared using non-parametric Wilcoxon rank sum test (Kruskal-Wallis 324 test) and Wilcoxon each pair test.

\subsection{Soil characterisation}


Except for the control substrate $(\mathrm{CN})$ with a $\mathrm{pH}$ value ca. 6, all soils of the PNCal area were alkaline including the technosols (E.C and E.S), being characteristic of local limestone soils (Fig. 1). SO had the lowest conductivity and SA the highest, but lower than $2000 \mu \mathrm{S} / \mathrm{cm}$. 331 Therefore, according to natural soil saline classification and conductivity data, all the PNCal 332 soils, as well as CN, may be considered as non-saline.

TOC values in all PNCal soils were very low except for SO, with an average value of 110 $\mathrm{mg} / \mathrm{g}$. The TOC values were 14 (CC) to 3.5 -fold lower (SO) than CN. No NTK differences were observed for SA and SO compared to $\mathrm{CN}$, although other NTK values were up to 7-fold lower (E.C, E.S) than CN. The fertility of these soils could be thus considered as low.

The texture of soils from the coastal sites (SA, TR and CC) was sandy loam as well as for $\mathrm{CN}$, but with less coarse sand for the latter (Fig. 1). The granulometry of SO soil corresponded to clay loam while the technosols (E.C, E.S) were sandy clay loam with coarser sand for E.S.

According to agronomic criteria (Fig. 1), soils from the coastal sites contained highest concentrations of exchangeable $\mathrm{Na}$ but also of the major fertility elements $(\mathrm{P}, \mathrm{Ca}, \mathrm{Mg}, \mathrm{K})$, with less exchangeable P for TR. The technosols (E.C, E.S) and the soil from SO had a low content of exchangeable $\mathrm{Na}$ but also of exchangeable $\mathrm{P}, \mathrm{Ca}, \mathrm{Mg}, \mathrm{K}$. As expected, $\mathrm{CN}$ presented good fertility indices.

The E.S and E.C technosols had the highest $\mathrm{Pb}$ and $\mathrm{Zn}$ contents whose varied from 1 to $3 \%$, and a very high content of As in E.C (about $0.3 \%$ ), but also high values of Fe, i.e. 1 to $5 \%$ as for all PNCal soils (Fig. 2 and supp. data 2).

We used the PLI to compare the relative load of the mixed pollution of the various soils. PLI for E.C and E.S soils were at least 20-fold higher than all the other soils i.e. PLI $_{\mathrm{E} . \mathrm{C}}=216$ and $\mathrm{PLI}_{\mathrm{E} . \mathrm{S}}=203$ whereas $\mathrm{PLI}_{\mathrm{SA}}=6, \mathrm{PLI}_{\mathrm{TR}} \& \mathrm{PLI}_{\mathrm{SO}}=4, \mathrm{PLI}_{\mathrm{CC}}=1.4$ since $\mathrm{PLI}_{\mathrm{CN}}=1.3$. This 

362

revealed a potentially high ecotoxicological risk associated with both technosols i.e. ingestion or inhalation of soil particles may expose biocoenosis to non negligible effects of trace elements.

Following these analyses, the loamy horticultural soil $(\mathrm{CN})$ could be considered as control soil and the soil of $\mathrm{CC}$ and $\mathrm{SO}$ were the least PNCal polluted soils, being also the least seaspray-affected of the four seashore soils.

\subsection{Germination test}

360 The percentage of germination after 14 days was $80 \%$ in the $\mathrm{CN}$ (Fig. 3), while significantly 361 lower for all the other soils tested (it varied from 20 to $60 \%$ ). However, the germination of this plant species was mostly affected by the combination of alkalinity and salinity (TR, Fig. 1). The germination percentage at 4 days was negatively correlated both with soil $\mathrm{pH}$ and conductivity (supp. data 3 ). The results also showed a weak negative correlation after 14 days with $\mathrm{Zn}\left(\mathrm{r}_{\mathrm{s}}=-0.45, \mathrm{p}\right.$-value $\left.<0.0001\right)$ and $\mathrm{Cu}\left(\mathrm{r}_{\mathrm{s}}=-0.45, \mathrm{p}\right.$-value $\left.<0.0001\right)$. Very weak negative correlations were observed for $\mathrm{As}\left(\mathrm{r}_{\mathrm{s}}=-0.30, \mathrm{p}\right.$-value $\left.<0.0001\right)$ and $\mathrm{Pb}\left(\mathrm{r}_{\mathrm{s}}=-0.28\right.$, $\mathrm{p}$-value $<0.0001)$. The negative correlation between germination and $\mathrm{pH}$ increased with time, while the correlation with exchangeable $\mathrm{Na}$ and conductivity decreased. The negative correlation between germination and soil $\mathrm{Zn}$ concentration increased with time. These results can be interpreted as a rapid osmotic effect for germination inhibition by conductivity, with possibly a partially transitory priming effect for $\mathrm{Na}$ (Capron et al., 2000) and a progressive

373 These results demonstrated the ability of A. halimus to germinate up to $50 \%$ even in the case 374 of soils containing up to $2500 \mathrm{mg} / \mathrm{kg}$ of As and up to $30000 \mathrm{mg} / \mathrm{kg}$ of $\mathrm{Pb}$ near the horizontal 
chimney (E.C), and the limitation of germination potential by $\mathrm{pH}$ alone or combined with salts for all the PNCal soils.

\subsection{Growth traits}

379 Overall, the growth traits expressed as percentages compared to control can be classified by 380 increasing order of effects, as follows: survival (given by the number of individuals) $<$ shoot 381 and root lengths $<$ shoot and root fresh weights $<$ leaf surface area (Fig. 4). In other words, 382 amongst growth traits, leaf surface, length and plant weight were the most significantly 383 inhibited with $60-90 \%$ reduction compared to control. After germination, individual loss 384 continued during plantlet growth up to $10-20 \%$ for TR whereas no significant losses were 385 observed for the four other PNCal soils. Reductions of all parameters except survival for E.C 386 and SO soils were significantly greater than those for SA soil. The growth traits were not 387 significantly inhibited for SA and only concerning leaf surface and shoot fresh weight for CC. 388 The growth traits not significantly inhibited were survival, shoot and root length for E.S and, 389 shoot length and root fresh weight for TR.

392 After 63 days, the highest indices of flavonol, betacyanin (refered as antocyanin index for 393 Multiplex ${ }^{\circledR}$ index) and phenol were obtained for plants grown in SO soil, whereas phenol and 394 betacyanin indices were the lowest in $\mathrm{CN}$ soil. Chlorophyll indices were the most stable, with 395 significantly lower values in E.S, E.C and CC soils than in other soils.

396 Monitoring of plant chemical traits with non-destructive index measurements (Fig. 5) enabled 397 observation of a time-dependent response. As a first step, betacyanin indices decreased in 
basal leaves and stems in $\mathrm{CN}$ and SA and increased in SO soils, immediately followed by an increase in chlorophyll index in all soils except $\mathrm{SO}$, then in phenol indices in all soils and finally a decrease in flavonol indices. The latter was concomitant with the appearance of necrosis in the basal leaves in E.C and E.S. Moreover, there were no specific visual symptoms of toxicity and/or necrosis on the other leaves and heterogeneity of betacyanin pigmentation developed in the same way from rib to limb on $\mathrm{CN}$ soil as on the PNCal soils. The general trend of the curves (Fig. 5) showed that this physiological succession was faster for the control. Thus part of the response of chemical traits may be due to the physiological stage of the seedlings.

\subsection{Metal and metalloid transfer to plants}

Concerning non-essential elements, the highest accumulations of $\mathrm{Pb}$ and $\mathrm{Sb}$ in roots were measured in E.C and E.S soils and for As in roots, only in E.C soil (Fig. 2). For CC and SO soils, $\mathrm{Sb}$ and $\mathrm{As}$ concentrations in roots were similar to those of the control whereas $\mathrm{Pb}$ concentrations were still above those of $\mathrm{CN}$. In some of the PNCal soils, $\mathrm{Pb}, \mathrm{As}$ and $\mathrm{Sb}$ concentrations in roots were not those of normal tissue concentrations but those of possibly harmful concentrations (Markert, 1994; Prasad et al., 2006). The major pollutants in root tissues were As and $\mathrm{Pb}$ in E.C soil, with $3439 \mathrm{mg} / \mathrm{kg}$ and $24444 \mathrm{mg} / \mathrm{kg}$ respectively, in accordance with the composition of the slag deposit from the smelter industrial activity. Metals and metalloids ( $\mathrm{As}, \mathrm{Pb}, \mathrm{Sb}, \mathrm{Zn}, \mathrm{Cu})$ present in soils were weakly transferred to the roots $(\mathrm{BCF}<1)$ (supp. data 4), except in the case of E.C for $\mathrm{As}, \mathrm{Pb}$ and $\mathrm{Zn}$, of $\mathrm{CN}$ for $\mathrm{Cu}$, of $\mathrm{SA}$ for $\mathrm{Cu}$ and $\mathrm{Sb}$, of $\mathrm{CC}$ for $\mathrm{As}, \mathrm{Cu}$ and $\mathrm{Zn}$, and of $\mathrm{SO}$ for $\mathrm{Cu}$. Even in the soil of E.C, there was a selective transfer of each of these elements between the soil and the root parts, as $\mathrm{Pb}$ was better transferred to root than $\mathrm{Sb}$ and $\mathrm{Zn}$ (Fig. 2). The transfer coefficients from soil to 
aerial parts were always $<1$ for $\mathrm{As}, \mathrm{Cu}, \mathrm{Fe}$ and $\mathrm{Pb}$ (supp. data 4). TF values were more than 1 in the case of $\mathrm{K}$ and $\mathrm{Na}$ for all conditions. TF values were only $>1$ for $\mathrm{Zn}$ in the case of $\mathrm{CN}$, $\mathrm{CC}$ and SO. Mn was present in soils at moderate to high concentrations, with higher concentrations in E.S, SO and SA soils. However, its transfer to shoots was particularly low in E.C, E.S and SA soils, although Mn TF value was high for the CN.

The elements that are regulators of osmotic pressure, e.g. $\mathrm{Na}$ and $\mathrm{K}$ (Fig. 2), were preferentially accumulated in shoots in all the soils tested. However, the concentration ratios between $\mathrm{Na}$ and $\mathrm{K}$ in shoots were strictly above 1 for TR and SA, and below 0.5 in all the other PNCal soils, while this ratio was equal to 0.51 for CN (supp. data 5).

\subsection{Root fungal colonization}

433 Two types of fungal structure were observed in A. halimus roots i.e. arbuscular mycorrhizal 434 fungi (AMF) and dark septate endophytes (DSE). Both kinds of symbiotic microorganisms 435 were present in all root systems for each of the PNCal soils. A discriminant analysis was applied on the percentages of each fungal structure (Fig. 6). Along the first dimension, there was a separation between $\mathrm{CN}$ and $\mathrm{CC}$, with a higher occurrence of AM colonization, and E.C and E.S with more DSE. In the second dimension, more arbuscules were observed in roots from CC and SO soils. With this analysis, three main groups may be identified: (i) CN, (ii) CC, TR, SA and SO, (iii) E.C and E.S. A strong correlation was detected between DSE colonisation percentages and $\mathrm{As}, \mathrm{Pb}$ and $\mathrm{Zn}$ concentrations in soils, with Spearman coefficients of $0.70,0.63$ and 0.56 , respectively ( $\mathrm{p}$-value $\leq 0.01$ ). DSE colonisation percentage was also negatively correlated with available P in soil (Spearman coefficient of 0.55 at $p$-value $\leq 0.01)$. 


\subsection{Do PNCal soils have good agronomic properties?}

448 The metal and metalloid contamination of PNCal soils has previously been partially studied and the diffuse pollution of these soils has been discussed in separate publications (Affholder et al., 2013; Heckenroth et al., 2016; Rabier et al., 2014; Testiati et al., 2013). However, in this study, soil characterization was completed by fertility parameters for the seashore sites. Soils were alkaline with $\mathrm{pH}$ ranging from 7.5 to 8.5 , typical of calcareous areas, but the highest exchangeable $\mathrm{Ca}$ and $\mathrm{K}$ values found for the soils from less polluted areas of the seashore were associated with the presence of scrap materials such as lime mortar for $\mathrm{Ca}$, and for $\mathrm{K}$ an origin that could be linked to bricks and tiles with aminosilicate of potassium as the active substance (Testiati et al., 2013). The soils from the seashore were mainly sandy clay soils, while the granulometry of the technosols from E.C and E.S had no relation with the mineralogy of natural soils. There was more fine dust in E.C without coarse sand and coarser sand and less fine dust in E.S soil. Technosol from E.C seemed to be very compact when dry, like real clay soil.

Concerning soil pollution, the strong correlation between $\mathrm{As}$ and $\mathrm{Pb}$, particularly for E.C soil, was probably related to their deposition as lead arsenate, while the correlation between As and $\mathrm{Sb}$ was explained by their belonging to the same group in the periodic table in relation to the same behaviour during the ore treatment and dust deposit in soils (Testiati et al., 2013). Sb concentrations were low in soils except for E.S and E.C, where $\mathrm{As}, \mathrm{Pb}, \mathrm{Zn}$ and $\mathrm{Cu}$, whose toxicity is more well-known, were also present at high concentrations.

467 Zn concentration was locally important (Testiati et al., 2013), which could be explained by 468 differences in ore origin during the smelter activity and use of pyrite in the former sodium 469 carbonate factories at the vicinity of the smelter factory (Daumalin and Raveux, 2016). 
The results of $\mathrm{Pb}$ and TOC for $\mathrm{SO}$ were a little above those of natural soils, but SO was not exempt from previous anthropogenic activities that took place at the beginning of the 19th century (Fressoz, 2013; Daumalin and Raveux, 2016).

In summary, the PNCal soils have low fertility with high $\mathrm{pH}$, high $\mathrm{Fe}$ content and low nutrient and TOC contents. The anthropogenic addition of materials maintained or increased $\mathrm{pH}$ and Fe concentration, but lowered TOC. Fertility was slightly increased for seashore sites in relation with domestic anthropogenic nitrogen deposition and a covering layer of excavated loam (Rabier et al., 2014). The positive common denominator of these soils is that high $\mathrm{pH}$, Fe and Mn oxides and low TOC lowered MM mobility and limited their transfer into plants and into marine ecosystems (Bert, 2012; Dang et al., 2014; Lenoble et al., 2015; Lin et al., 2008; Martínez-Sánchez et al., 2011). The higher fertility level compared to the other PNCal soils of the coastal area where spontaneous $A$. halimus populations are exclusively localized for the moment may be a driving parameter for A. halimus development.

\subsection{Is A. halimus able to germinate in all the PNCal soils?}

485 The results showed that $\mathrm{pH}, \mathrm{Na}$ and $\mathrm{Zn}$ were involved in A. halimus germination inhibition. 486 The data of $\mathrm{pH}$ and soil composition were in accordance with those of studies of germination 487 inhibition whose differentiated the effect of alkalinity from salinity (Chen et al., 2010; Ma et 488 al., 2015). Sodium soil concentration may explain the delay of germination shown by the 489 characteristic S-shaped aspect of germination for seashore soils which has been observed for 490 some other Atriplex species and other Chenopodiaceae (Capron et al., 2000; Katembe et al., 491 1998). The effect of multiple metals and metalloids is difficult to appreciate because they 492 occur simultaneously in the field and their presence is correlated with other factors such as salinity and alkalinity. The correlation between $\mathrm{Zn}$ and germination rate was weak, which is 
in accordance with other studies under controlled conditions showing no effect of separated $\mathrm{Cu}, \mathrm{Pb}$ or $\mathrm{Zn}$ treatments for A. halimus sub. schweinfurthii (Lotmani et al., 2011) and separated $\mathrm{Cu}$ or Zn treatments for A. halimus sub. halimus (Márquez-García et al., 2013).

Finally, our results indicated that the potential for widespread dissemination of A. halimus by seed germination is very limited in the PNCal soils. Previous test of germination with an agronomic plant species i.e. Raphanus sativus showed a percentage of germination of $83 \pm 6$, $72 \pm 9$ and $90 \pm 3$ on E.C, SO and CN soils respectively (unpublished data), confirming the low capacity of $A$. halimus to develop on other soils than the type on which it spontaneously develops compared to an agronomic species.

\subsection{A. halimus growth inhibition in PNCal soils}

Reduced additional individual losses were shown during plant growth monitoring for TR. 506 However, a growth inhibition of as much as $60-80 \%$ for the less polluted soils was observed. 507 This demonstrated a negative impact on growth of these mainly oligotrophic soils, 508 independently of their pollution level. This is in accordance with the studies by other authors 509 on A. halimus (Martínez-Fernández and Walker, 2012), which have shown that nutrient 510 supply rather than heavy metals $(\mathrm{Pb}, \mathrm{Zn})$ limits growth of A. halimus. Moreover, A. halimus 511 grows well in nutrient-rich solution (Lutts et al., 2004) and is described as halo-nitrophilous 512 (Muñoz-Rodríguez, 2012; Walker et al., 2014). Coastal sites of the PNCal are popular and 513 often crowded during summer, generating illicit waste deposits. Moreover, permanent 514 indigenous human presence at the site of Marseilleveyre can be dated back at least to $600 \mathrm{AC}$ 515 (Bouffier and Garcia, 2014). This could coincide with the introduction of A. halimus species 516 among the halonitrophilous taxa of the Chenopodiaceae, though older evidence of the 517 presence of Atriplex species has been found in pollen from Calanques sediment (Romey et al., 
5182015 and 2014). However, it is not possible to distinguish between the species by their palynogical character (Abel-Schaad et al., 2014; Fernández-Illescas et al., 2010). Though a potential spread of A. halimus at the expense of native leguminous plant species does exist in theory, especially considering Astragalus tragacantha, a protected native plant species on the seashore and, Coronilla juncea, another native plant species, at the chimney site, it is limited by the nitrogen contribution of these species which is probably negligible in comparison with the anthropogenic nitrogen sources. These results are in accordance with our previous results as A. halimus is spontaneously present on disturbed soils from the seashore and inland in presence of waste from building, but not on the more polluted part of the former smelter nor in undisturbed mattoral. Moreover, it has been previously demonstrated that A. tragacantha shows no difference of growth in a soil analogous to TR compared to a loamy reference soil after two years of culture (Laffont-Schwob et al., 2011) although A. halimus had a significantly reduced growth in TR compared to $\mathrm{CN}$.

Consequently, for the $\mathrm{PNCal}$, if it seeks to manage A. halimus dispersion due to its potential invasiveness, the priority action would be to reduce dog droppings and organic matter deposits resulting from human practices that favour preferential habitats for A. halimus rather than to eradicate $A$. halimus individuals themselves.

\subsection{Root symbiosis: the secret weapon to success for A. halimus?}

Symbionts were ubiquitous in all root systems, whatever the PNCal soil tested, indicating their occurrence in soils, in contrast to what it is observed on more recently disturbed soils with reduced fungal inoculum (Brundrett, 2009). As previously confirmed from aerial photography archives, the soils from these sites, heavily contaminated and disturbed during the industrial period, have been less disturbed since 1960 for the seashore sites and ca. 1950 
for E.C as the roof of the smelter horizontal chimney had clearly been destroyed (Rabier et al., 2014; IGN 1943; IGN 1950). It was probably destroyed by bombing during the battle of Marseille in August 1944 (Duchêne and Contrucci, 1998). It appears that a sufficient period of time has passed for a spontaneous symbiont spore bank to be formed in these polluted soils. Moreover, antimony microbial tolerance of soils from the same site has been shown by respiration measurements, demonstrating an adaptation of the PNCal soil microbial populations (Guillamot et al., 2014). Even if the genus Atriplex was previously quoted as nonmycorrhizal (Brundrett, 2009), recent papers showed the occurrence of root symbioses in many species belonging to this genus (Sonjak et al., 2009). The occurrence of symbionts in the roots of $A$. halimus has already been proven in natura in the Calanques National Park (Laffont-Schwob et al., 2011; Rabier et al., 2014) suggesting an old occurrence of this plant species in the area. As previously discussed, though these sites are peri-urban, which explains the spontaneous presence of nitrophilous species such as A. halimus, the perturbation of the entisol was sufficiently old to allow the development of a spontaneous fungal spore bank. The positive correlation between MM and DSE is in accordance with several authors (Ban et al., 2012; Xu et al., 2015; Zhang et al., 2008), and a previous work on Rosmarinus officinalis at E.C (Affholder et al., 2014). However contrasting results can be found in the literature and are related to the plant's strategy to increase its tolerance to MM (see review by Göhre and Paszkowski, 2006). Recently, there has been a surge in research focused on how DSE could restrict the uptake of metals by their host plants and especially the interactions of metal ions with melanins (Felix et al., 1978; Fogarty and Tobin, 1996; Mandyam and Jumpponen, 2005; Mugerwa et al., 2013; Stainsack et al., 2003). However, the ability of fungal symbionts to 564 limit metal transfer from soil to A. halimus may not be the only factor involved. It has 565 recently been proven that A. halimus, with its own biosynthesis of enzymes and antioxydants, 566 may bind, sequestrate and reduce the harmful effect of trace metals (El-Bakatoushi et al., 
2015). Consequently the occurrence of this plant species in coastal polluted soils may not 568 increase the potential transfer of MM to the food chain and may favour phytostabilization.

\subsection{Decision-making criteria for the PNCal to maintain or eradicate A. halimus}

571 In response to the question of whether A. halimus is able to grow on more or less polluted or 572 salt-affected soils from the PNCal - in other terms, in soils different from those in which it spontaneously grows, - the answer is yes. However, a high loss of $50 \%$ at the germination stage was observed. The results also showed $80 \%$ growth reduction for the surviving plants in the two technosols (E.C and E.S.). Moreover, the controlled conditions used mimicked the field conditions except for xericity, providing more favourable conditions than the in natura ones. The nitrophilous character of $A$. halimus also limits its potential for the colonization of new territory. Thus, the oligotrophic and less polluted soils of $\mathrm{CC}$ and SO showed a significant reduction of growth, while that of SA exhibited better growth results and higher chlorophyll indices associated with more widely available micronutrients, despite its significant pollution.

Given the low translocation factors, our results confirm that the individuals of $A$. halimus growing naturally on polluted soils along the coast do not present a risk of transfer of pollutants to aerial parts and the food chain and are tolerant to MM. It would appear that the germination and growth of this species require disturbed soil sites with increased macronutrient availability and associated symbionts. On the basis of these results, the PNCal is considering maintaining $A$. halimus stands in the polluted soils of the coastal area until a better ecological solution for pollution containment is found. 


\section{Conclusion}

From this case study, we wanted to reconsider the simplistic vision of pollution treatment vs biological conservation in polluted protected areas. In various cases, plants spontaneously growing in polluted areas are adapted to pollution and may prevent pollutant transfer. The potential invasiveness of these pollutant-tolerant plants in such field may be easily experienced by analysing biotic and abiotic factors favouring their germination and growth in ex-situ assays and give decisional tools for the protected area managers.

\section{Acknowledgements}

599 The authors thank Laurent Vassalo and Carine Demelas for their analytical assistance for 600 trace and major element measurements. We are grateful to Xavier Daumalin for information 601 on the industrial history of the Calanques. Many thanks to Régine Verlaque for helpful 602 discussions on the biogeographical distribution of A. halimus and the determination of the 603 chromosome number of A. halimus. The authors are grateful to Lidwine Le Mire Pécheux, of 604 the Calanques National Park, for helpful discussion on environmental management, and thank 605 Michael Paul for reviewing the English text. This work has been carried out partly thanks to 606 the support of the A*MIDEX project ( ${ }^{\circ}$ ANR-11-IDEX-0001-02) funded by the 607 Investissements d'Avenir French Government program, managed by the French National 608 Research Agency (ANR) (project named SynTerCalM). This research has been made possible 609 by participation in the EU COST Action FA 0901, favouring links between scientists of 610 various countries on halophytes. Many thanks to the Calanques National Park and the CD13 611 for providing access to the field. 
Abbad, A., Cherkaoui, M., Wahid, N., El Hadrami, A., Benchaabane, A., 2004. Variabilités phénotypique et génétique de trois populations naturelles d'Atriplex halimus. CR. Biol. 327, 371-380.

617 Abel-Schaad, D., López-Sáez, J.A., Pulido, F., 2014. Heathlands, fire and grazing. A 618 palaeoenvironmental view of Las Hurdes (Cáceres, Spain) history during the last 1200 years. 619 Forest Systems 23, 247-258.

620 Affholder, M.C., Pricop, A.D., Laffont-Schwob, I., Coulomb, B., Rabier, J., Borla, A., 621 Demelas, C., Prudent, P., 2014. As, Pb, Sb, and $\mathrm{Zn}$ transfer from soil to root of wild 622 rosemary: do native symbionts matter? Plant Soil 382, 219-236.

623 Affholder, M.C., Prudent, P., Masotti, V., Coulomb, B., Rabier, J., Nguyen-The, B., Laffont624 Schwob, I., 2013. Transfer of metals and metalloids from soil to shoots in wild rosemary 625 (Rosmarinus officinalis L.) growing on a former lead smelter site: human exposure risk. Sci. 626 Total Environ. 454-455, 219-229.

627 Affre, L., Suehs, C.M., Charpentier, S., Vilà, M., Brundu, G., Lambdon, P., Traveset, A., 628 Hulme, P.E., 2010. Consistency on the habitat degree of invasion for three invasive plant 629 species across Mediterranean islands. Biological Invasions 12, 2537-2548.

630 Agati, G., Cerovic, Z.G., Pinelli, P., Tattini, M., 2011. Light induced accumulation of ortho631 dihydroxylated flavonoids as non-destructively monitored by chlorophyll fluorescence 632 excitation techniques. Environ. Exp. Bot. 73, 3-9.

633 Armendáriz-Villegas, E.J., Covarrubias-García, M.A., Troyo-Diéguez, E., Lagunes, E., 634 Arreola-Lizárraga, A., Nieto-Garibay, A., Beltrán-Morales, L.F., Ortega-Rubio, A., 2015. 
Metal mining and natural protected areas in Mexico: Geographic overlaps and environmental implications. Environ. Sci. Policy 48, 9-19.

Baize, D., 2000. Guide des analyses en pédologie, second ed. Institut de la Recherche Agronomique, Paris. ISBN: 2-7380-0892-5.

639 Ban, Y., Tang, M., Chen, H., Xu, Z., Zhang, H., Yang, Y., 2012. The response of dark septate 640 endophytes (DSE) to heavy metals in pure culture. PLoS One 7(10) doi: 641 10.1371/journal.pone.0047968. Epub 2012 Oct 31.

642 Bandiera, M., Dal Cortivo, C., Barrion, G., Mosca, G., Vamerali, T., 2016. Phytoremediation 643 opportunities with alimurgic species in metal-contaminated environments. Sustainability 8 $644 \quad 357,1-17$. doi:10.3390/su8040357.

645 Bert, V., 2012. Les phytotechnologies appliquées aux sites et sols pollués. Etat de l'art et 646 guide de mise en œuvre, ed. EDP Sciences / ADEME / INERIS, Les Ulis. ISBN: 978-2-7598$647 \quad 0805-2$.

648 Bouffier, S., Garcia, D., 2014. Les territoires de Marseille antique, ed. Errance-Actes Sud, 649 Arles. ISBN: 978-2-87772-570-5.

650 Brundrett, M.C., 2009. Mycorrhizal associations and other means of nutrition of vascular 651 plants: understanding the global diversity of host plants by resolving conflicting information 652 and developing reliable means of diagnosis. Plant Soil 320, 37-77.

653 Caçador I., Duarte, B., 2015. Chromium Phyto-transformation in Salt Marshes: The Role of 654 Halophytes, in: Ansari, A.A., Gill, S.S., Gill, R., Lanza, G.R., Nexman, L. (Eds.), 655 Phytoremediation: Management of Environmental Contaminants, Volume 2, Springer 656 International Publishing Switzerland, pp. 211-217. ISBN: 978-3-319-10969-5. 
Capron, I., Corbineau, F., Dacher, F., Job, C., Côme, D., Job, D., 2000. Sugarbeet seed 658 priming: effects of priming conditions on germination, solubilization of 11-S globulin and accumulation of LEA proteins. Seed Sci. Res. 10, 243-254.

Cerovic, Z.G., Moise, N., Agati, G., Latouche, G., Ben Ghozlen, N., Meyer, S., 2008. New portable optical sensors for the assessment of winegrape phenolic maturity based on berry fluorescence. J. Food Compos. Anal. 21, 650-654.

Chen, W., Chi, Y., Taylor, N.L., Lambers, H., Finnegan, P.M., 2010. Disruption of ptLPD1 or ptLPD2, genes that encode isoforms of the plastidial lipoamide dehydrogenase, confers arsenate hypersensitivity in Arabidopsis. Plant Physiol. 153, 1385-1397.

Dang, D.H., Tessier, E., Lenoble, V., Durrieu, G., Omanović, D., Mullot, J.U., Pfeifer H.R., Mounier S., Garnier, C., 2014. Key parameters controlling arsenic dynamics in coastal sediments: an analytical and modeling approach. Mar. Chem. 161, 34-46.

Daumalin, X., Laffont-Schwob, I., 2016. Pollution of Marseille's Industrial Calanques: The impact of the Past on the Present, ed. Ref2c, Aix-en-Provence. ISBN : 978-2-918582-27-4.

Daumalin, X., Raveux, O., 2016. The Calanques: a dumping ground for high-polluting industries, in: Daumalin, X., Laffont-Schwob, I., (Eds.), Pollution of Marseille's Industrial Calanques: The impact of the Past on the Present, ed. Ref2c, Aix-en-Provence, 11-91. ISBN: $978-2-918582-27-4$.

Desrousseaux, M., Ugo, E., 2016. Analyse juridique de la pollution diffuse du massif de marseilleveyre. Presses Universitaires d'Aix-Marseille, Aix-en-Provence, 164 pp.

Duchêne, R., Contrucci, J., 1998. Marseille, 2600 ans d'histoire, ed. Fayard, Paris. ISBN: $978-270284221$. 
679 El-Bakatoushi, R., Alframawy, A.M., Tammam, A., Youssef, D., El-Sadek, L., 2015. 680 Molecular and Physiological Mechanisms of Heavy Metal Tolerance in Atriplex halimus. Int. 681 J. Phytoremediat. 17, 789-800.

682 Felix, C.C., Hyde, J.S., Sarna, T., Sealy, R.C., 1978. Interactions of melanin with metal ions. 683 Electron spin resonance evidence for chelate complexes of metal ions with free radicals. J. 684 Am. Chem. Soc. 100, 3922-3926.

685 Fernández-Illescas, F., Nieva, F.J.J., Silva, I., Tormo, R., Muñoz, A.F., 2010. Pollen 686 production of Chenopodiaceae species at habitat and landscape scale in Mediterranean salt 687 marshes: An ecological and phenological study. Rev. Palaeobot. Palyno. 161, 127-136.

688 Fogarty, R.V., Tobin, J.M., 1996. Fungal melanins and their interactions with metals. Enzyme 689 Microb. Tech. 19, 311-317.

690 Fressoz, J.B., 2013. Payer pour polluer. L'industrie chimique et la compensation des 691 dommages environnementaux, 1800-1850. Histoire \& mesure 1/2013 (XXVIII), 145-186. $692 \mathrm{http} / / /$ histoiremesure.revues.org/4734

693 Göhre, V., Paszkowski, U., 2006. Contribution of the arbuscular mycorrhizal symbiosis to 694 heavy metal phytoremediation. Planta 223, 1115-1122.

695 Guillamot, F., Calvert, V., Millot, M.V., Criquet, S., 2014. Does antimony affect microbial 696 respiration in Mediterranean soils? A microcosm experiment. Pedobiologia 57, 119-121.

697 Heckenroth, A., Rabier, J., Dutoit, T., Torre, F., Prudent, P., Laffont-Schwob, I., 2016. 698 Selection of native plants with phytoremediation potential for highly contaminated 699 Mediterranean soil restoration: tools for a non-destructive and integrative approach. J. Env. 700 Manage. 183 (3), 850-863. 
701

1

2

IGN (Institut national de l'information géographique et forestière), 1943. France \& IGNF 702 PVA _ 1-0 _1943-12-28_C3639-0691_1943_33S26-3051, scale 1: 13.811, 13008 ;

703 Marseille 8e Arrondissement retrieved from http://geoportail.gouv.fr. (accessed 21 October 704 2015).

705 IGN (Institut national de l'information géographique et forestière), 1950. France \& IGNF _PVA_1-0_1950-08-30_C3445-0051_1950_F3145-3545_0410, scale 1: 27.752, Marseille 707 8e Arrondissement retrieved from http://geoportail.gouv.fr. (accessed 21 October 2015).

708 Katembe, W.J., Ungar, I.A., Mitchell, J.P., 1998. Effect of salinity on germination and 709 seedling growth of two Atriplex species (Chenopodiaceae). Ann. Bot-London 82, 167-175.

710 Keiffer, C.H., Ungar, I., 1997. The effect of extended exposure to hypersaline conditions on 711 the germination of five inland halophyte. Am. J. Bot. 84, 104-111.

712 Kidd, P., Mench, M., Álvarez-López, V., Bert, V., Dimitriou, I., Friesl-Hanl, W., Herzig, R., 713 Janssen, J.O., Kolbas, A., Müller, I., Neu, S., Renella, G., Ruttensg, A., Vangronsveld, J., 714 Puschenreiter, M., 2015. Agronomic practices for improving gentle remediation of trace 715 element-contaminated soils. Int. J. Phytorem. 17(11), 1005-1037. DOI: $716 \quad 10.1080 / 15226514.2014 .1003788$.

717 Laffont-Schwob, I., Dumas, P.J., Pricop, A., Rabier, J., Miché, L., Affre, L., Masotti, V., 718 Prudent, P., Tatoni, T., 2011. Insights on metal-tolerance and symbionts of the rare species 719 Astragalus tragacantha aiming at phytostabilization of polluted soils and plant conservation. 720 Ecol. Mediterr. 37, 57-62.

721 Laffont-Schwob, I., Heckenroth, A., Rabier, J., Masotti, V., Oursel, B., Prudent, P., 2016. 722 Diffuse and widespread present-day pollution, in: Daumalin, X., Laffont-Schwob, I., (Eds.), 
723 Pollution of Marseille's Industrial Calanques: The impact of the Past on the Present, ed.

724 Ref2c, Aix-en-Provence, pp. 205-249. ISBN: 978-2-918582-27-4.

725 Lavene, H., 1995. Les bétalaïnes: approche métabolique et étude de leur implication dans la 726 réponse à une contrainte saline de quelques centrospermales. $\mathrm{PhD}$ thesis, Rennes 1 727 University.

728 Le Houérou, H.N., 1992. The role of saltbushes (Atriplex spp.) in arid land rehabilitation in 729 the Mediterranean Basin: a review. Agroforest. Syst. 18, 107-148.

730 Lenoble, V., Dang, D.H., Cazalet, M.L., Mounier, S., Pfeifer, H.R., Garnier, C., 2015. 731 Evaluation and modelling of dissolved organic matter reactivity toward As III and As V732 Implication in environmental arsenic speciation. Talanta 134, 530-537.

733 Lin, H.T., Wang, M.C., Seshaiah, K., 2008. Mobility of adsorbed arsenic in two calcareous 734 soils as influenced by water extract of compost. Chemosphere 71, 742-749.

735 LoPresti, E.F., 2015. Chemicals on plant surfaces as a heretofore unrecognized, but 736 ecologically informative, class for investigations into plant defence. Biol. Rev. Camb. Philos. 737 Soc. 91(4), 1102-1117. doi: 10.1111/brv.12212.

738 Lotmani, B., Fatarna, L., Berkani, A., Rabier, J., Prudent, P., Laffont-Schwob, I., 2011. 739 Selection of Algerian populations of the Mediterranean saltbush, Atriplex halimus, tolerant to 740 high concentrations of lead, zinc, and copper for phytostabilization of heavy metal741 contaminated soils. The European Journal of Plant Science and Biotechnology 5, 20-26.

742 Lutts, S., Lefèvre, I., 2015. How can we take advantage of halophyte properties to cope with 743 heavy metal toxicity in salt-affected areas? Ann. Bot-London 115, 509-528. 
744 Lutts, S., LefèvreI., Delpérée, S., Kivits, S., Dechamps, C., Robledo, A., Correal, E., 2004.

745 Heavy metal accumulation by the halophyte species Mediterranean saltbush. J. Environ. Qual. $746 \quad 33,1271-1279$.

747 Ma, H., Yang, H., Lü, X., Pan, Y., Wu, H., Liang, Z., Ooi, M.K., 2015. Does high pH give a 748 reliable assessment of the effect of alkaline soil on seed germination? A case study with 749 Leymus chinensis (Poaceae). Plant Soil 394, 35-43.

750 McArthur, E.D., Sanderson, C., 1984. Distribution, systematics and evolution of 751 Chenopodiaceae: an overview, in: Tiedemann, A.R., McArthur, E.D., Stutz, H.C., Stevens, 752 R., Johnson, K.L. (Eds), Proceedings, Symposium on the Biology of Atriplex and Related 753 Chenopods, May 2-6 1983; Provo, Utah (USA), General Technical Report INT-172, United 754 States Department of Agriculture Forest Service ed., pp. 14-23.

755 Mandyam, K., Jumpponen, A., 2005. Seeking the elusive function of the root-colonising dark 756 septate endophytic fungi. Stud. Mycol. 53, 173-189.

757 Manousaki, E., Kalogerakis, N., 2009. Phytoextraction of $\mathrm{Pb}$ and Cd by the Mediterranean 758 saltbush (Atriplex halimus L.): metal uptake in relation to salinity. Environ. Sci. Pollut. R. 16, $759 \quad 844-854$

760 Markert, B., 1994. Plants of Biomonitors-Potential Advantages and Problems, in: Adriano, 761 D.C., Chen, Z.S., Yang, S.S., (Eds), Biochemistry of Trace Elements, Science and 762 Technology Letters, Northwood, New York, pp. 601-613.

763 Márquez-García, B., Márquez, C., Sanjosé, I., Nieva, F.J.J., Rodríguez-Rubio, P., Muñoz764 Rodríguez, A.F., 2013. The effects of heavy metals on germination and seedling 765 characteristics in two halophyte species in Mediterranean marshes. Mar. Pollut. Bull. 70, 119- 
767

Martínez-Fernández, D., Walker, D.J., 2012. The effects of soil amendments on the growth of

768 Atriplex halimus and Bituminaria bituminosa in heavy metal-contaminated soils. Water Air 769 Soil Pollut. 223, 63-72.

770 Martínez-Sánchez, M.J., Martínez-López, S., García-Lorenzo, M.L., Martínez-Martínez, L.B., 771 Pérez-Sirvent, C., 2011. Evaluation of arsenic in soils and plant uptake using various 772 chemical extraction methods in soils affected by old mining activities. Geoderma 160, 535773541

774 Mazurek, R., Kowalska, J., Gasiorek, M., Zadrozny, P., Józefowska A. Zaleski ,T., Kepka, 775 W., Tymczuk, M., Orlowska, K., 2017. Assessment of heavy metals contamination in surface 776 layers of Roztocze National Park forest soils (SE Poland) by indices of pollution. 777 Chemosphere 168, 839-850.

778 Mendez, M.O., Maier, R.M., 2008. Phytostabilization of mine tailings in arid and semiarid 779 environments - An emerging remediation technology. Environ. Health Persp. 16(3), 278-283.

780 Mugerwa, T.M., Saleeba, J.A., McGee, P.A., 2013. A variety of melanised root-associated 781 fungi from the Sydney basin form endophytic associations with Trifolium subterraneum. 782 Fungal Ecol. 6, 70-82.

783 Muñoz-Rodríguez, A.F., Rodríguez-Rubio, P., Nieva, F.J.J., Fernández-Illescas, F., Sánchez784 Gullón, E., Soto, J.M., Márquez-García, B., 2012. Importance of bracteoles in ensuring the 785 germination in optimal conditions and improving seedling vigor in Atriplex halimus. Fresen. 786 Environ. Bull. 21, 3521-3526.

787 Ortíz-Dorda, J., Martínez-Mora, C., Correal, E., Simón, B., Cenis, J.L., 2005. Genetic 788 structure of Atriplex halimus populations in the Mediterranean Basin. Ann. Bot-London 95, $789 \quad 827-834$ 
790

1

Otal, J., Orengo, J., Quiles, A., Hevia, M., Fuentes, F., 2010. Characterization of edible 791 biomass of Atriplex halimus L. and its effect on feed and water intakes, and on blood mineral 792 profile in non-pregnant Manchega-breed sheep. Small Ruminant Res. 91, 208-214.

793 Pardo, T., Clemente, R., Martínez-Fernández, D., Walker, D.J., Bernal, M.P., 2014. The use 794 of Atriplex halimus for the phytostabilisation of trace elements contaminated soils under semi795 arid climate: evaluation of soil health improvement, in: Proceedings of COST ACTION FA 796 0901: Final meeting, Putting Halophytes to Work From Genes to Ecosystems, Coimbra, 797 Portugal, 9-10 April 2014.

798 Percy, J., 1870. The metallurgy of lead: including desilverisation and cupellation, Murray J. 799 ed., London. https://archive.org/details/metallurgyleadi01percgoog.

800 Pérez-Esteban, J., Escolástico, C., Ruiz-Fernández, J., Masaguer, A., Moliner, A., 2013. 801 Bioavailability and extraction of heavy metals from contaminated soil by Atriplex halimus. 802 Environ. Exp. Bot. 88, 53-59.

803 Prasad, M.N.V., Sajwan, K.S., Naidu R., 2006. Trace elements in the environment: 804 biogeochemistry, biotechnology and bioremediation, CRC Press Taylor \& Francis ed., USA. 805 ISBN: 978-1566706858.

806 Rabier, J., Laffont-Schwob, I., Bouraïma-Madjèbi, S., Léon, V., Prudent, P., Viano, J., 807 Nabors, W.M., Pilon-Smits, E.A.H., 2007. Characterization of metal tolerance and 808 accumulation in Grevillea exul var exul. Int. J. Phytorem. 9, 419-435.

809 Rabier, J., Laffont-Schwob, I., Pricop, A., Ellili, A., D’enjoy-Weinkammerer, G., Salducci, 810 M.D., Prudent, P., Lotmani, B., Tonetto, A., Masotti, V., 2014. Heavy metal and arsenic 811 resistance of the halophyte Atriplex halimus L. along a gradient of contamination in a French 812 Mediterranean spray-zone. Water Air Soil Pollut. 225,1993. 
813

1

Rashed, M.N., 2010. Monitoring of contaminated toxic and heavy metals, from mine tailings

814 through age accumulation, in soil and some wild plants at Southeast Egypt. J. Hazard. Mater. $815 \quad 178,739-746$

816 Romey, C., Vella, C., Rochette, P., Andrieu-Ponel, V., Magnin, F., Veron, A., Talon, B., 817 Landuré, C., D’Ovidio, A.M., Delanghe, D., Ghilardi, M., Angeletti, B., 2015. Environmental 818 imprints of landscape evolution and human activities during the Holocene in a small 819 catchment of the Calanques Massif (Cassis, southern France). Holocene 25, 1454-1469.

820 Romey, C., Rochette, P., Vella, C., Arfib, B., Andrieu-Ponel, V., Braucher, R., Champollion, 821 C., Douchet, M., Dussouillez, P., Hermitte, D., Mattioli, E., Parisot, J.C., Schwenninger, J.L., 822 2014. Geophysical and geomorphological investigations of a Quaternary karstic paleolake and 823 its underground marine connection in Cassis (Bestouan, Cassis, SE France). Geomorphology $824214,402-415$

825 Simberloff, D., 2011. How common are invasion-induced ecosystem impacts? Biol. Invasions 826 13, 1255-1268. doi: 10.1007/s10530-011-9956-3

827 Słomka, A., Sutkowska, A., Szczepaniak, M., Malec, P., Mitka, J., Kuta, E., 2011. Increased 828 genetic diversity of Viola tricolor L. (Violaceae) in metal-polluted environments. 829 Chemosphere 83, 435-442.

830 Snow, R., 1963. Alcoholic hydrochloric acid-carmine as a stain for chromosomes in squash 831 preparations. Biotech. Histochem. 38, 9-13.

832 Sonjak, S., Udovic, M., Wraber, T., Likar, M., Regvar, M., 2009. Diversity of halophytes and 833 identification of arbuscular mycorrhizal fungi colonising their roots in an abandoned and 834 sustained part of Secovlje saltern. Soil Biol. Biochem. 41, 1847-1856. 
835 Stainsack, J., Mangrich, A.S., Maia, C.M., Machado, V.G., dos Santos, J.C., Nakagaki, S., 836 2003. Spectroscopic investigation of hard and soft metal binding sites in synthetic melanin. 837 Inorg. Chim. Acta 356, 243-248.

838 Talamali, A., Hours, M., Gorenflot, R., Dutuit, P., 2004. Variations phénologiques, 839 morphologiques et niveaux de ploïdie chez Atriplex halimus L. (Amaranthaceae). Rev. Cytol. 840 Biol. Veg. Bot. 27, 31-41.

841 Testiati, E., Parinet, J., Massiani, C., Laffont-Schwob, I., Rabier, J., Pfeifer, H.R., Lenoble, 842 V., Masotti, V., Prudent, P., 2013. Trace metal and metalloid contamination levels in soils and 843 in two native plant species of a former industrial site: evaluation of the phytostabilization 844 potential. J. Hazard Mater. 248, 131-141.

845 Vangrosveld, J., Herzig, R., Weyens, N., Boulet, J., Adriaensen, K., Ruttens, A., Thewys, T., 846 Vassilev, A., Meers, E., Nehnevajova, E., van der Lelie, D., Mench, M., 2009. 847 Phytoremediation of contaminated soils and groundwater: lessons from the field. Environ Sci 848 Pollut Res 16, 765-794.

849 Vierheilig, H., Coughlan, A.P., Wyss, U., Piché, Y., 1998. Ink and vinegar, a simple staining 850 technique for arbuscular-mycorrhizal fungi. Appl. Environ. Microb. 64, 5004-5007.

851 Walker, D.J., Lutts, S., Sánchez-García, M., Correal, E., 2014. Atriplex halimus L.: its biology 852 and uses. J. Arid Environ. 100, 111-121.

853 Walker, D.J., Moñino, I., González, E., Frayssinet, N., Correal, E., 2005. Determination of 854 ploidy and nuclear DNA content in populations of Atriplex halimus (Chenopodiaceae). Bot. J. 855 Linn. Soc. 147, 441-448.

856 Xu, R., Li, T., Cui, H., Wang, J., Yu, X., Ding, Y., Wang, C., Yang, Z., Zhao, Z., 2015. 857 Diversity and characterization of Cd-tolerant dark septate endophytes (DSEs) associated with 
858 the roots of Nepal alder (Alnus nepalensis) in a metal mine tailing of southwest China. Appl.

1
859 Soil Ecol. 93, 11-18.

860 Yoon, J., Cao, X., Zhou, Q., Ma, L.Q., 2006. Accumulation of Pb, Cu and Zn in native plants 861 growing on a contaminated Florida site. Sci. Total Environ. 368,456-464.

862 Zhang, X., Zhang, S., Xu, X., Li, T., Gong, G., Jia, Y., Li, Y., Deng, L., 2010. Tolerance and 863 accumulation characteristics of cadmium in Amaranthus hybridus L. J. Hazard. Mater. 180, $864 \quad 303-308$

865 Zhang, Y., Zhang, Y., Liu, M., Shi, X., Zhao, Z., 2008. Dark septate endophyte (DSE) fungi 866 isolated from metal polluted soils: their taxonomic position, tolerance, and accumulation of 867 heavy metals in vitro. J. Microbiol. 46, 624-632. 


\section{Figures}

Fig. 1: Physico-chemical characteristics of the PNCal soils and control. Parameters: EC: electrical conductivity, TOC: total organic carbon, NTK: total Kjeldahl nitrogen, Exch. $\mathrm{P}_{2} \mathrm{O}_{5}$ : exchangeable $\mathrm{P}$ mg/kg $\mathrm{P}_{2} \mathrm{O}_{5}$, Exch. $\mathrm{Na}, \mathrm{K}, \mathrm{Mg}$, Ca: exchangeable $\mathrm{Na}, \mathrm{K}, \mathrm{Mg}, \mathrm{Ca}(\mathrm{mg} / \mathrm{g})$, CEC: cationic exchange capacity (Metson cmol $+/ \mathrm{kg}$ ). Sites: CN: control; SA: Calanque de Saména; TR: Calanque des Trous; CC: Cap Croisette; E.C: Escalette Chimney; E.S: Escalette Slagheap; SO: Sormiou.

Fig. 3: Effect of PNCal soil contamination and/or salinity on germination of A. halimus during the 14 days of the experiment. Different letters above mean values $(n=10, p \leq 0.05)$ indicate significant difference (Wilcoxon test).

Fig. 4: Growth traits and survival (as percentage of control) for A. halimus in the PNCal soils, $\mathrm{n}=10, \mathrm{p} \leq 0.05)$. Sites: CN: control; SA: Calanque de Saména; TR: Calanque des Trous; CC: Cap Croisette; E.C: Escalette Chimney; E.S: Escalette Slagheap; SO: Sormiou. Different letters above mean values ( \pm standard error $(\mathrm{SE})$ ) indicate significant difference for the same parameter (Wilcoxon test). 
Fig. 5: Monitoring of chlorophyll, flavonol, anthocyanin and leaf epidermal phenol indices in 894 A. halimus leaves depending on PNCal soils types $(\mathrm{n}=10, \mathrm{p} \leq 0.05)$. Different letters following 895 curves indicate significant difference for the same parameter (Wilcoxon test).

Fig. 6: Canonical plot of results of discriminant analysis with the percentages of each fungal structure (A: arbuscule, M: mycelium, V: vesicle and DSE: dark septate endophytes), and the 7 soil types as parameters $\left(\mathrm{n}=3\right.$ and $\mathrm{F}_{(24,39)}=7.67, \mathrm{P}<0.0001$; Wilk's Lamda $=0.002$; Canonical1 $=59.9 \%$, Canonical2=28.3\%). For each category, inner and outer circles represent the $95 \%$ confidence intervals for the means and the $50 \%$ prediction intervals, respectively. The seven soil types explain $59.9 \%$ and $28.3 \%$ of the observed variance in fungal occurrence on axis 1 and 2, respectively.

\section{Supplementary data:}

Supp. data 1: Map of soil sampling locations (SA: Calanque de Saména; TR: Calanque des Trous; CC: Cap Croisette; E.C: Escalette Chimney; E.S: Escalette Slagheap; SO: Sormiou) and seed sampling location (E) in the Calanques national park (PNCal).

Supp. data 2: Average metal and metalloid concentrations $(\mathrm{mg} / \mathrm{kg}$ of dry weight) in soil samples from each soil type. Different letters following means \pm standard error (SE) in a column indicate significant difference $(n=3, p \leq 0.05$, Wilcoxon test).

Supp. data 3: Evolution of Spearman correlations between germination percentages and soil parameters up to 15 days after imbibition $(n=10, p \leq 0.05) . \rho X, Y$ : Spearman correlation, $\mathrm{X}=\mathrm{G}$ : germination percentage, $\mathrm{Y}=\mathrm{pH}, \mathrm{EC}, \mathrm{TOC},(\mathrm{Na})$ : $\mathrm{Na}$ concentration, ( $\mathrm{Zn}) \mathrm{Zn}$ concentration. The Line of Fit element shows a linear regression with confidence intervals in shady colors. 
917 Supp. data 4: Bioaccumulation factor (BCF) and translocation factor (TF) values for each

1

2

6
918 metal and metalloid in A. halimus growing on the different soil types. Different letters 919 following means \pm standard error $(\mathrm{SE})$ in a column indicate significant difference $(\mathrm{n}=3$, $920 \mathrm{p} \leq 0.05$, Wilcoxon test).

921 Supp. data 5: $\mathrm{Na} / \mathrm{K}$ ratio in different soil types, and in root and shoot of $A$. halimus growing 922 on these different soils. Different letters following means \pm standard error (SE) in a column 923 indicate significant difference $(n=3, p \leq 0.05$, Wilcoxon test). 


\section{Figure1}

Click here to download Figure: Figure1 new.pdf
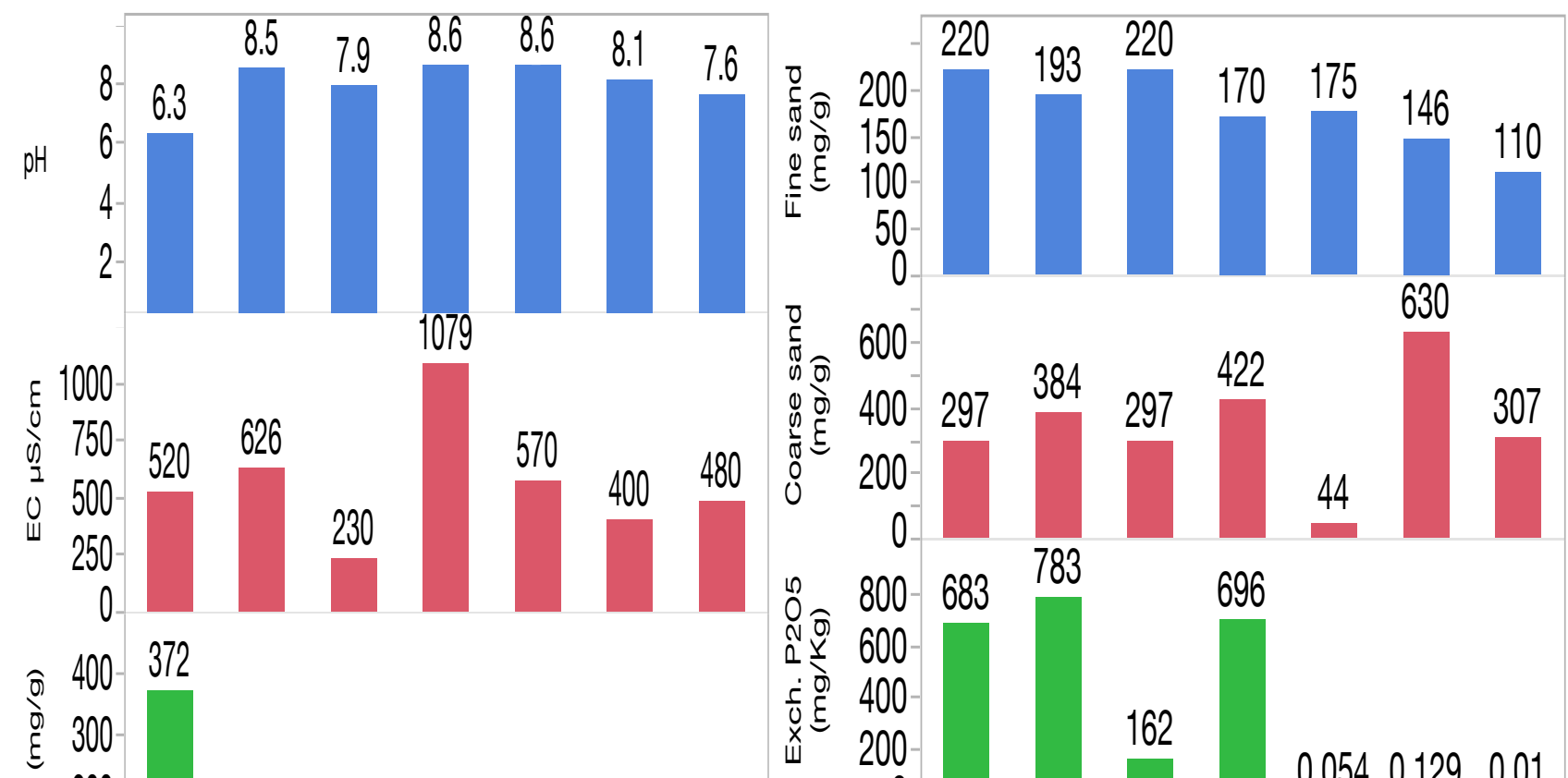

ติ๊

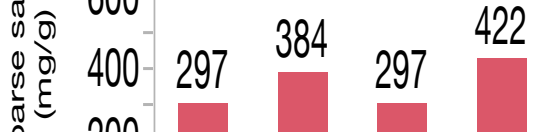

$200-$
0

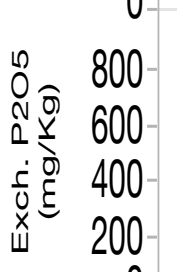

$0 \quad 200$

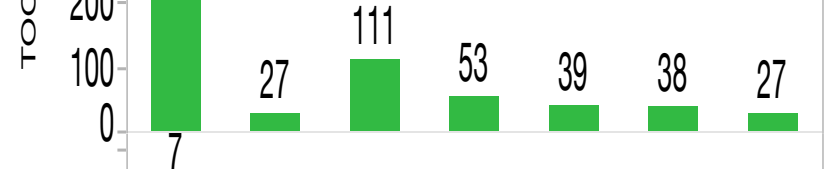
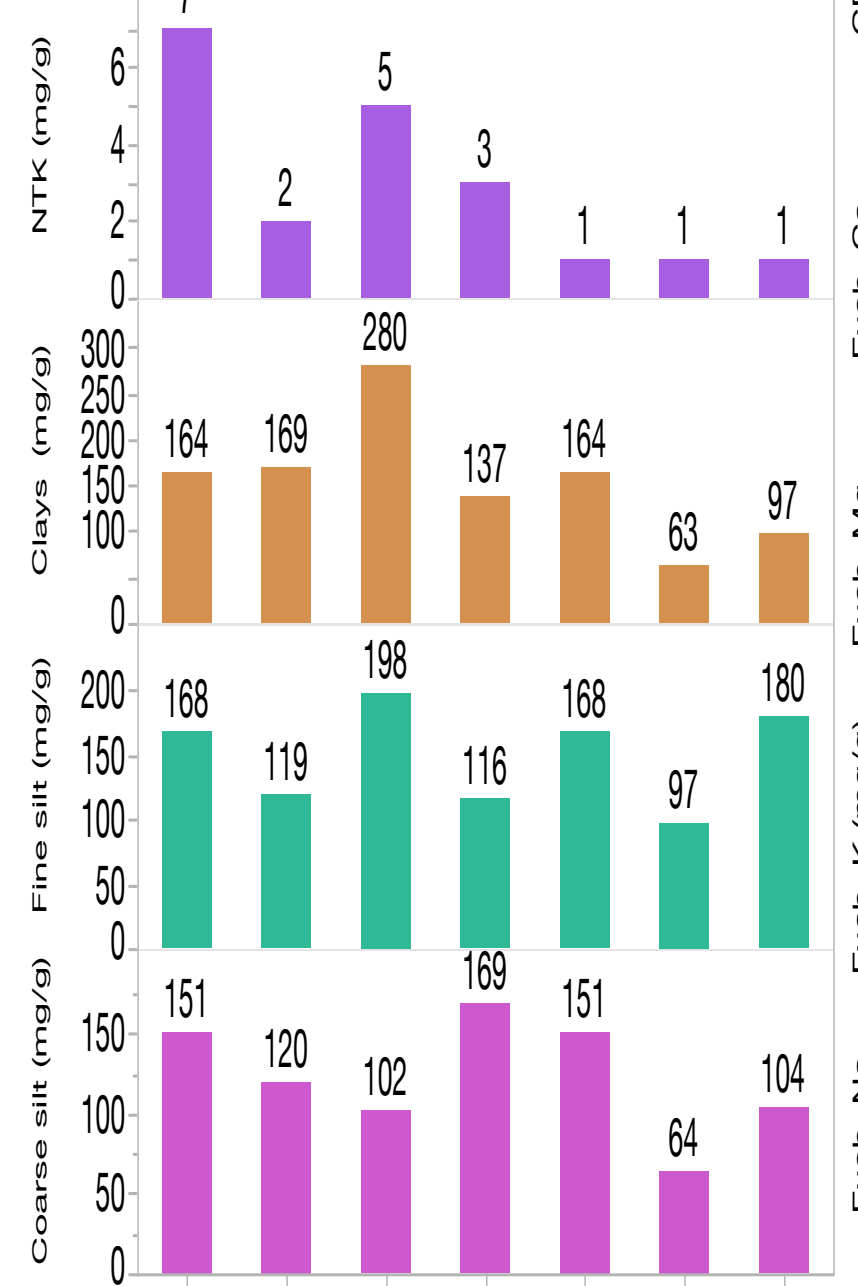

CN SA TR CC E.C E.S SO

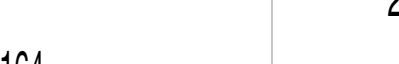

65.4

162

696

0.0540 .1290 .01

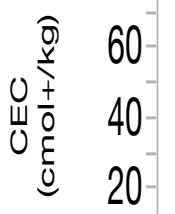

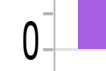

$\begin{array}{lllll}15.1 & 8.9 & 12 & 9.34 & 8.31\end{array}$

27.3

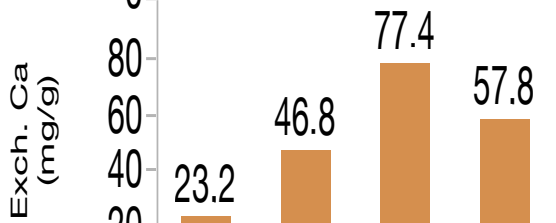

0

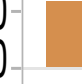

.26

$7.98 \quad 6.61 \quad 5.58$

0.05460 .07240 .186

0

1.46
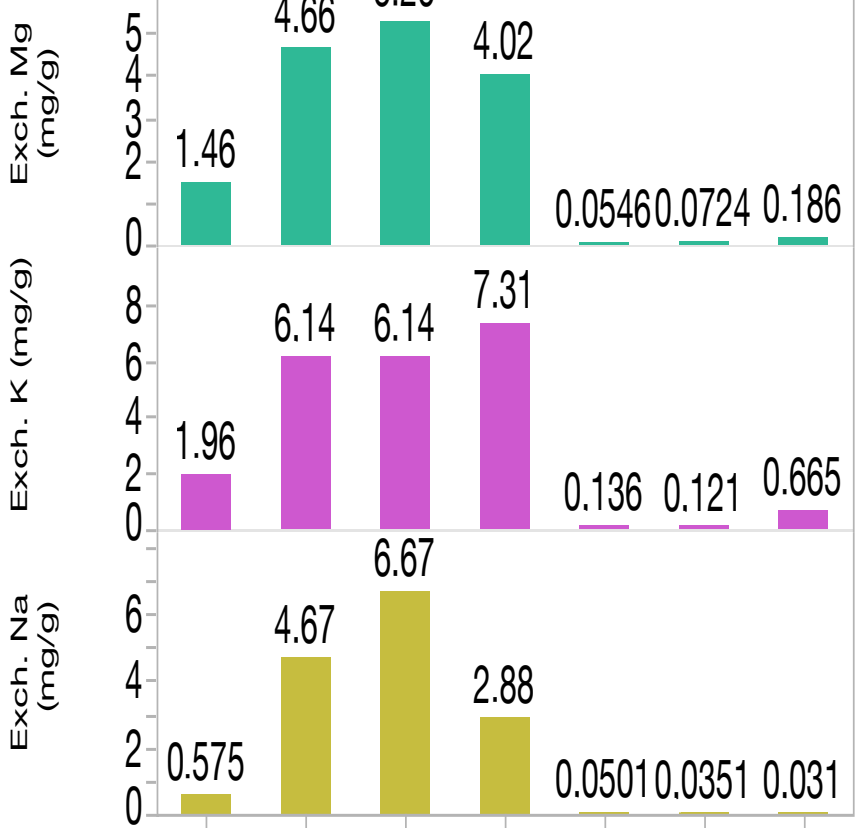

CN SA TR CC E.C E.S SO Site 


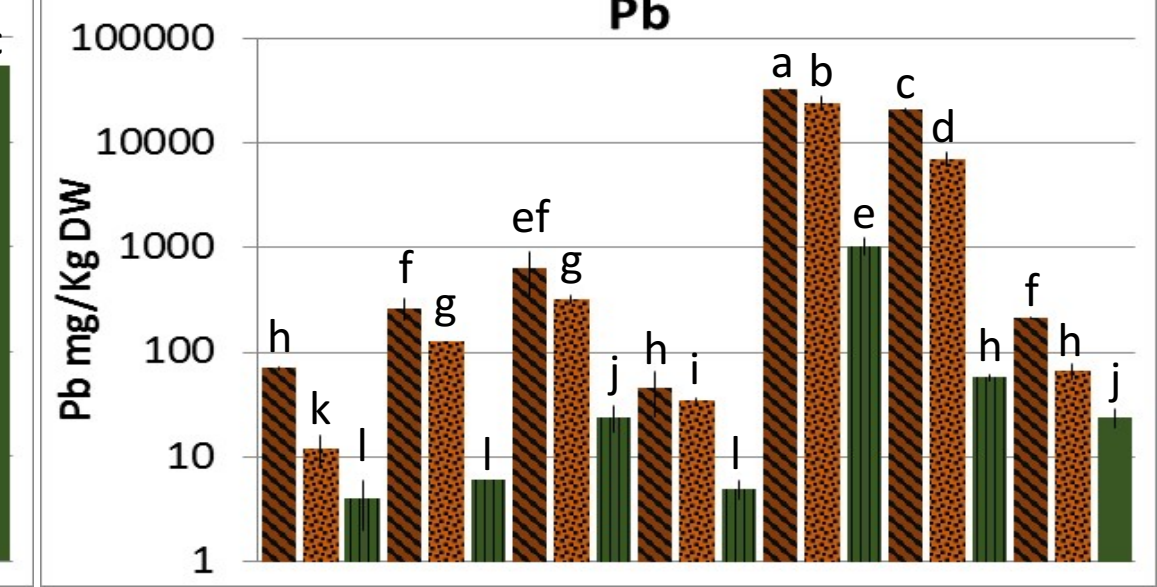

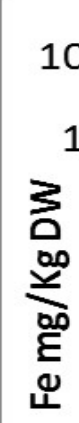
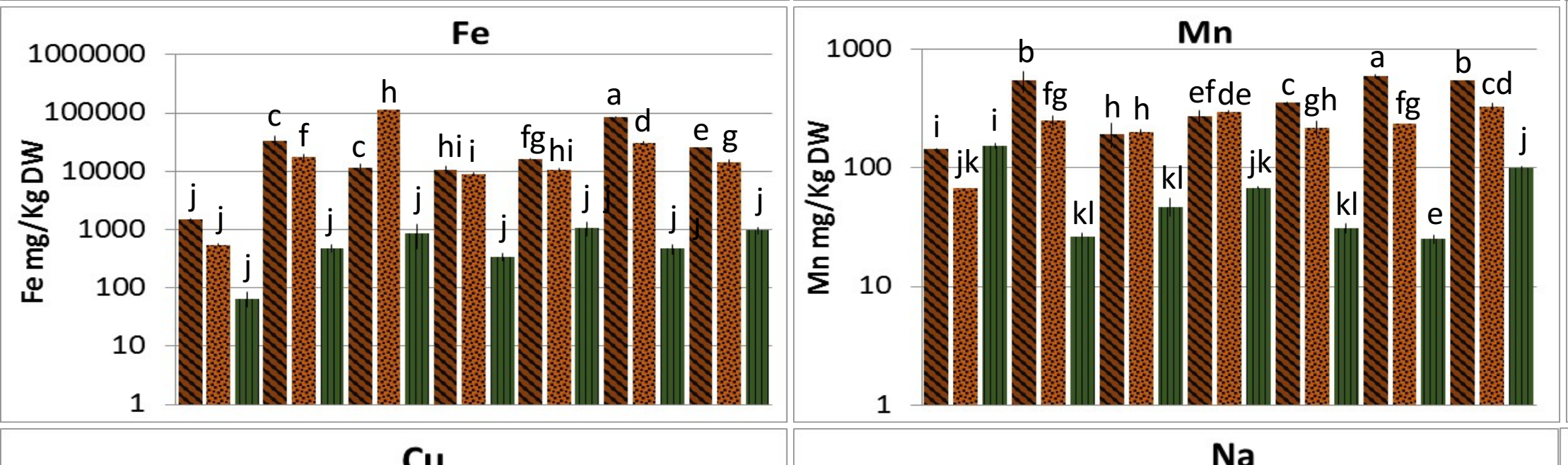

$$
10000
$$

Sb
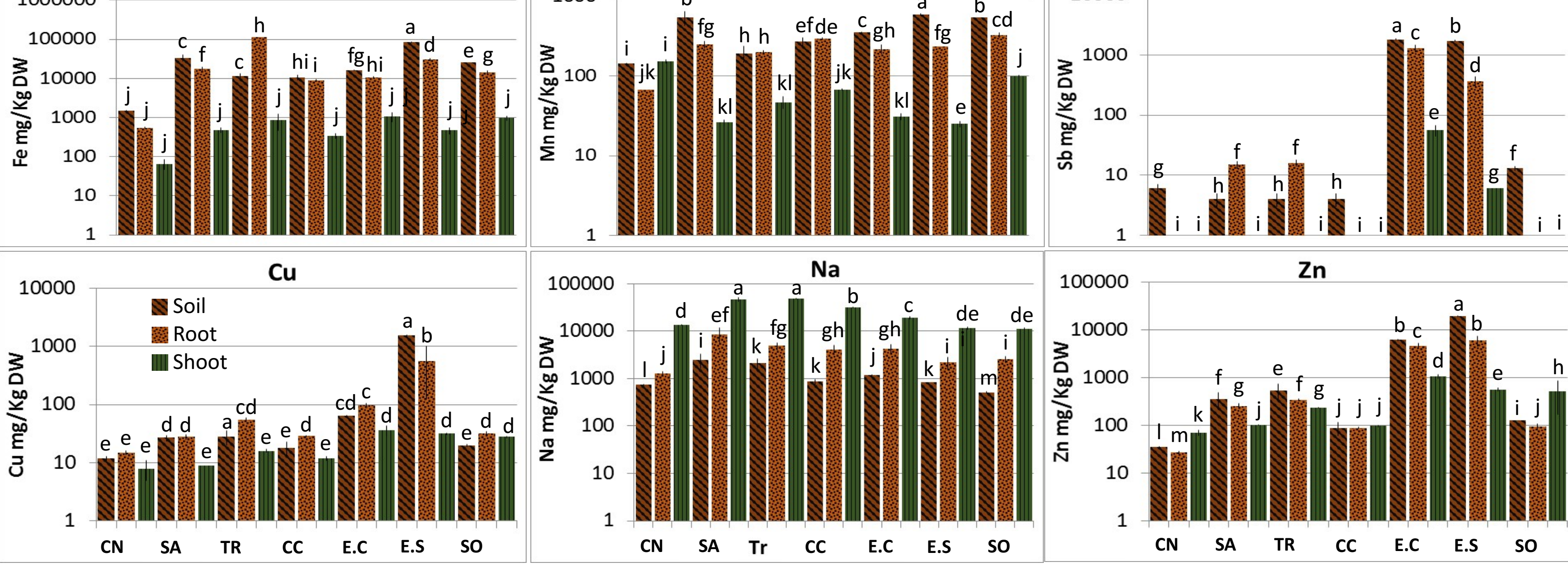


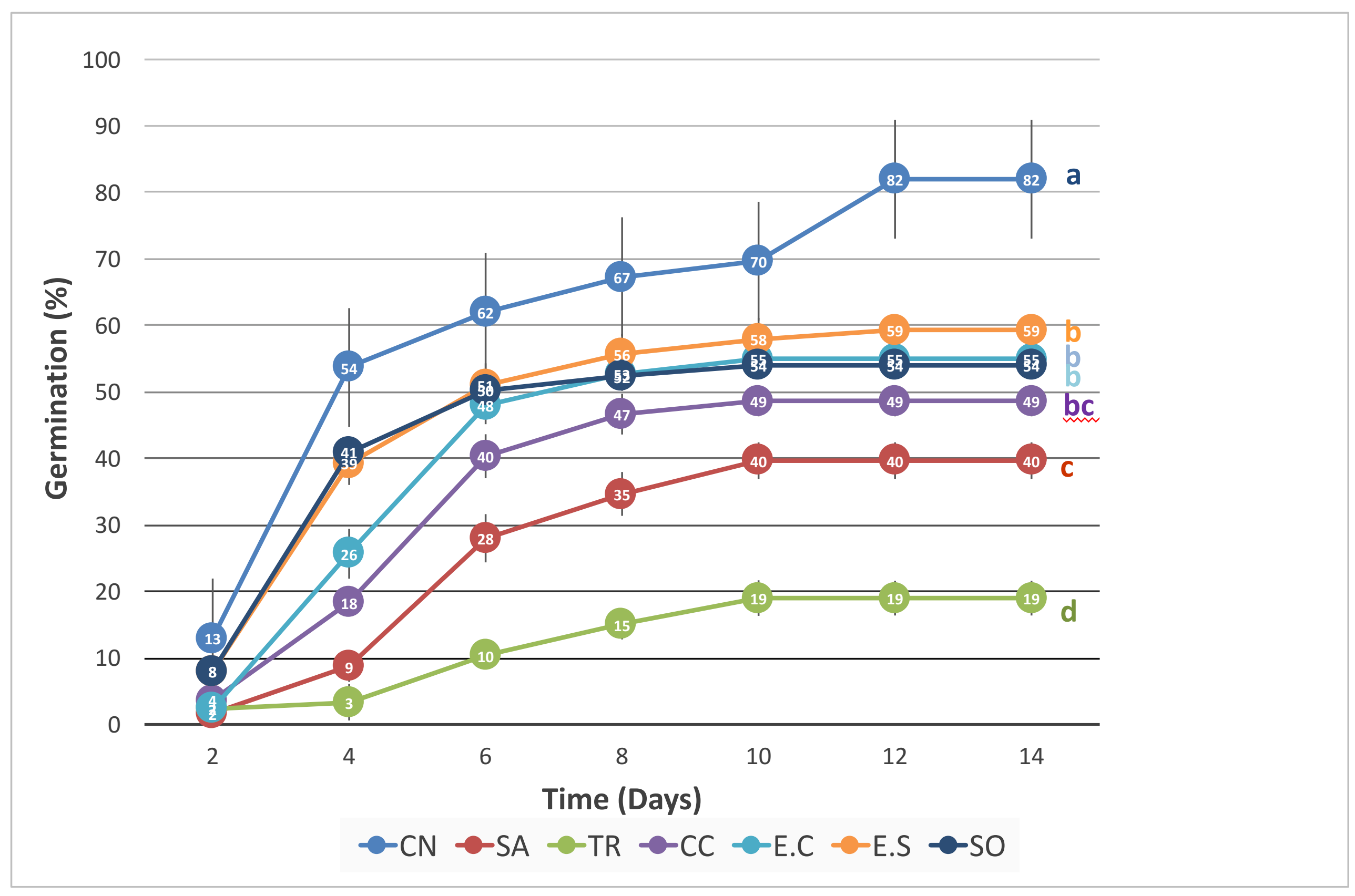




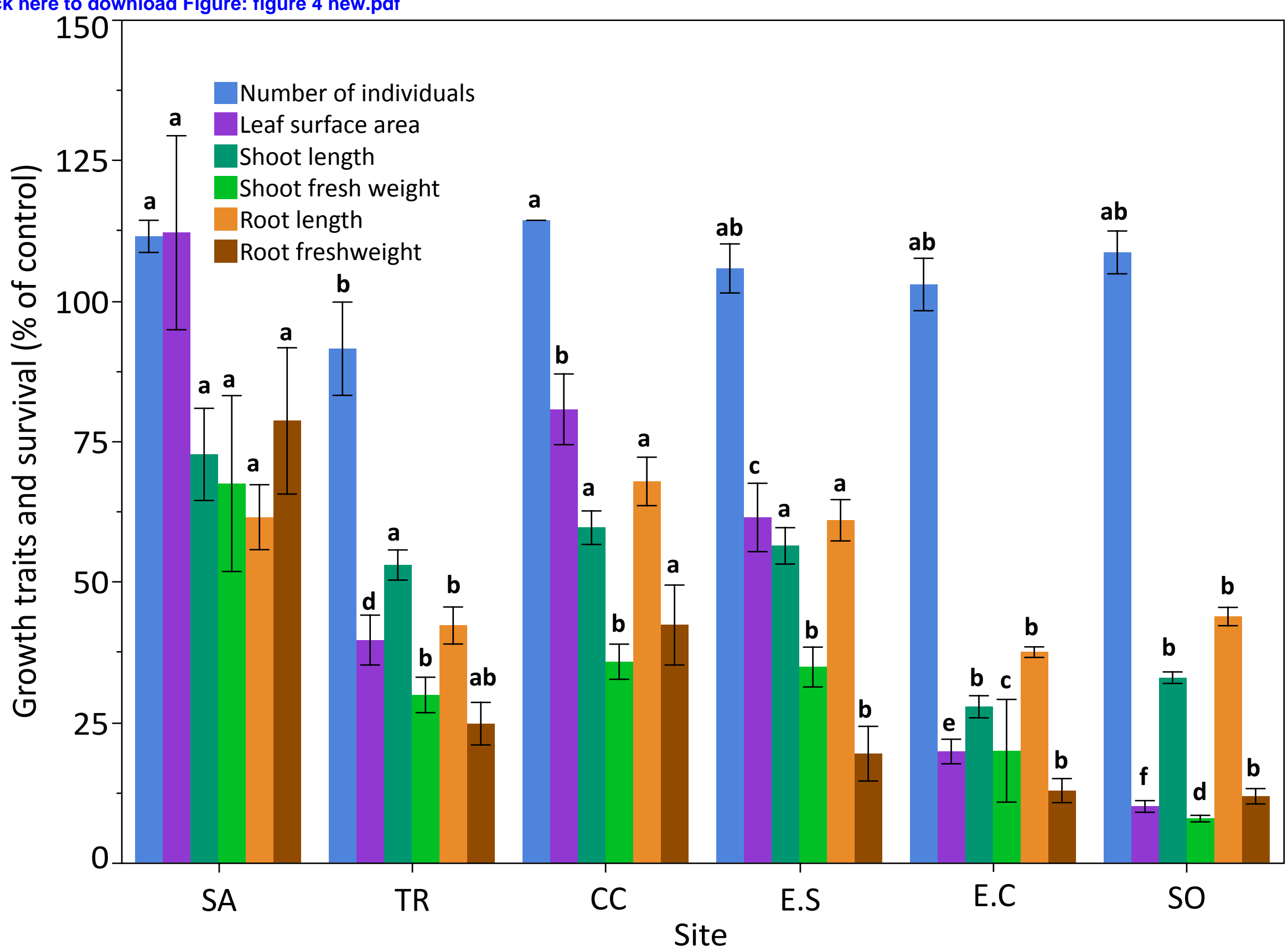




\section{Figure 5,6
Click here}

Click here to-download Figure: figure5 new.pdf
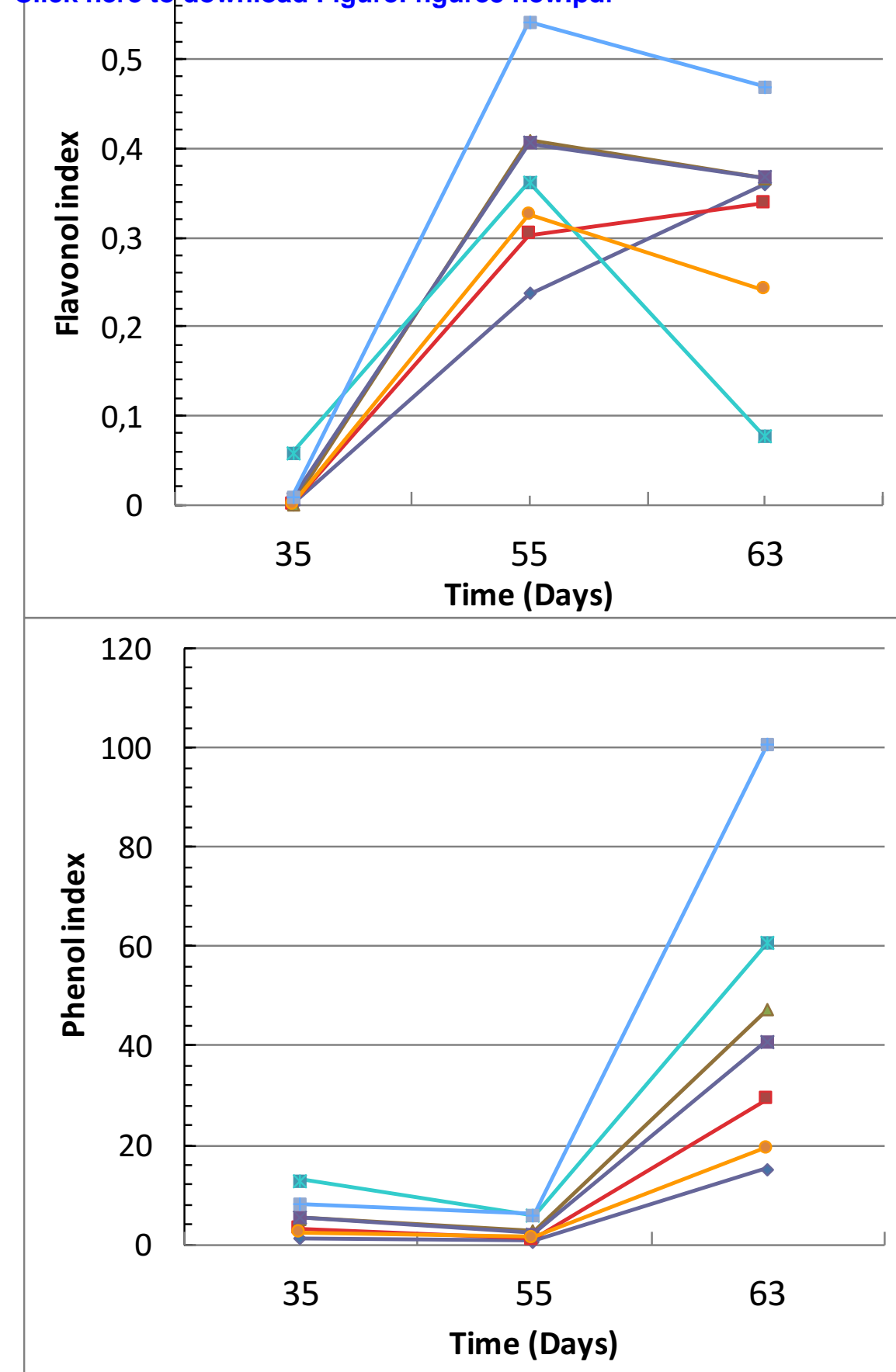
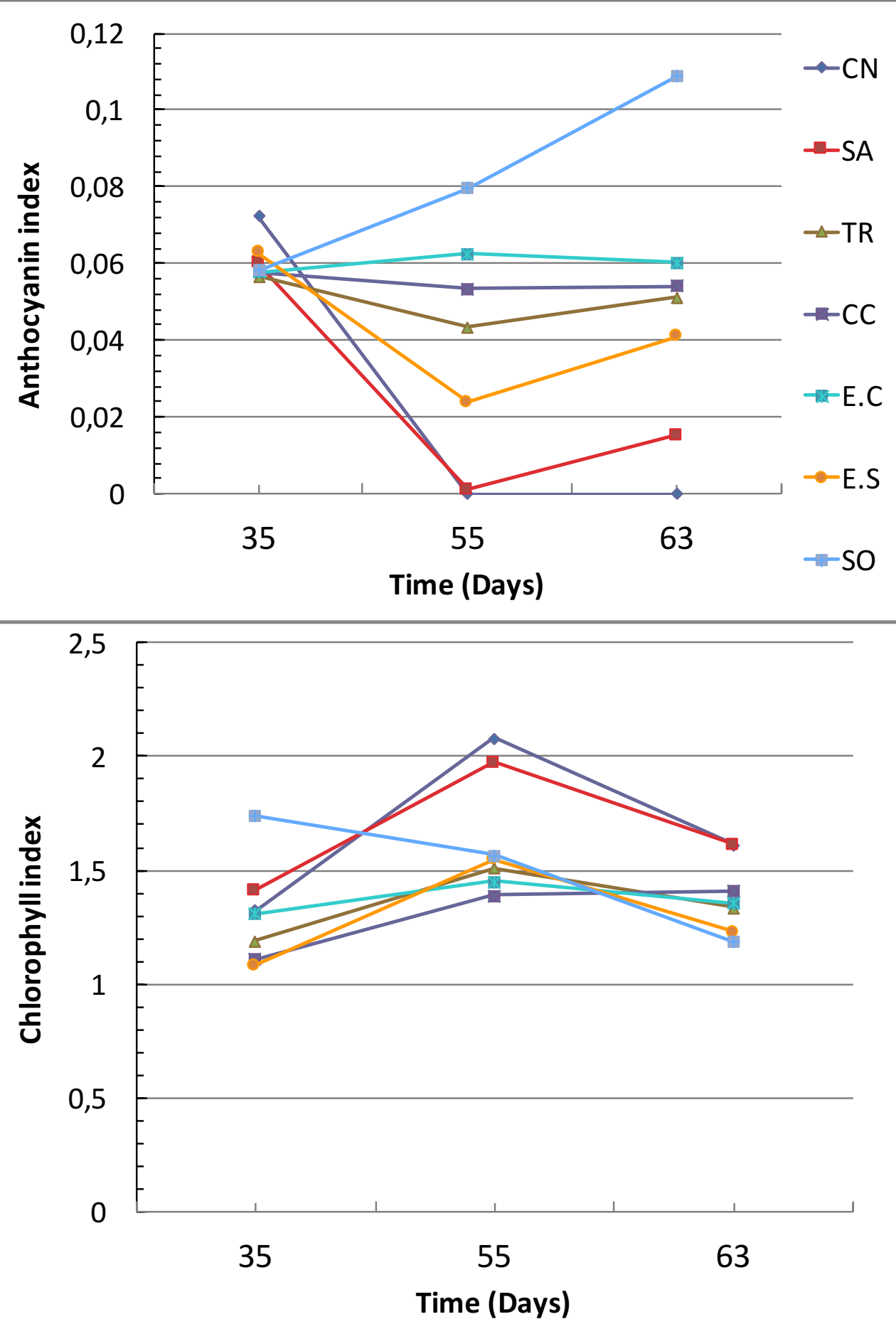
Supplementary data 2: Average metal and metalloid concentrations ( $\mathrm{mg} / \mathrm{kg}$ of dry weight) in soil samples from each soil type.

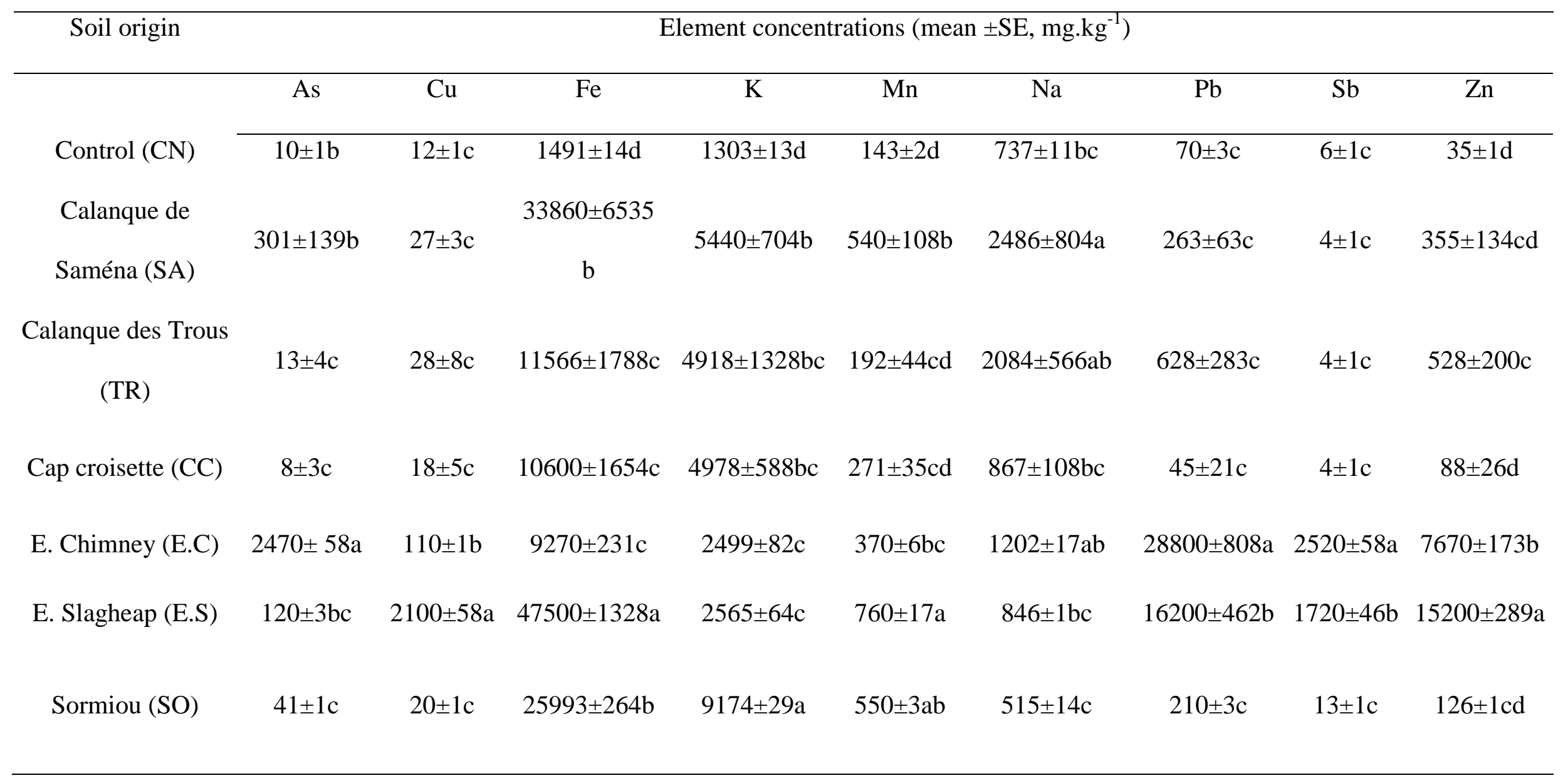

Different letters following means \pm standard error $(\mathrm{SE})$ in a column indicate significant difference $(\mathrm{n}=3, \mathrm{p} \leq 0.05$, Wilcoxon test). 


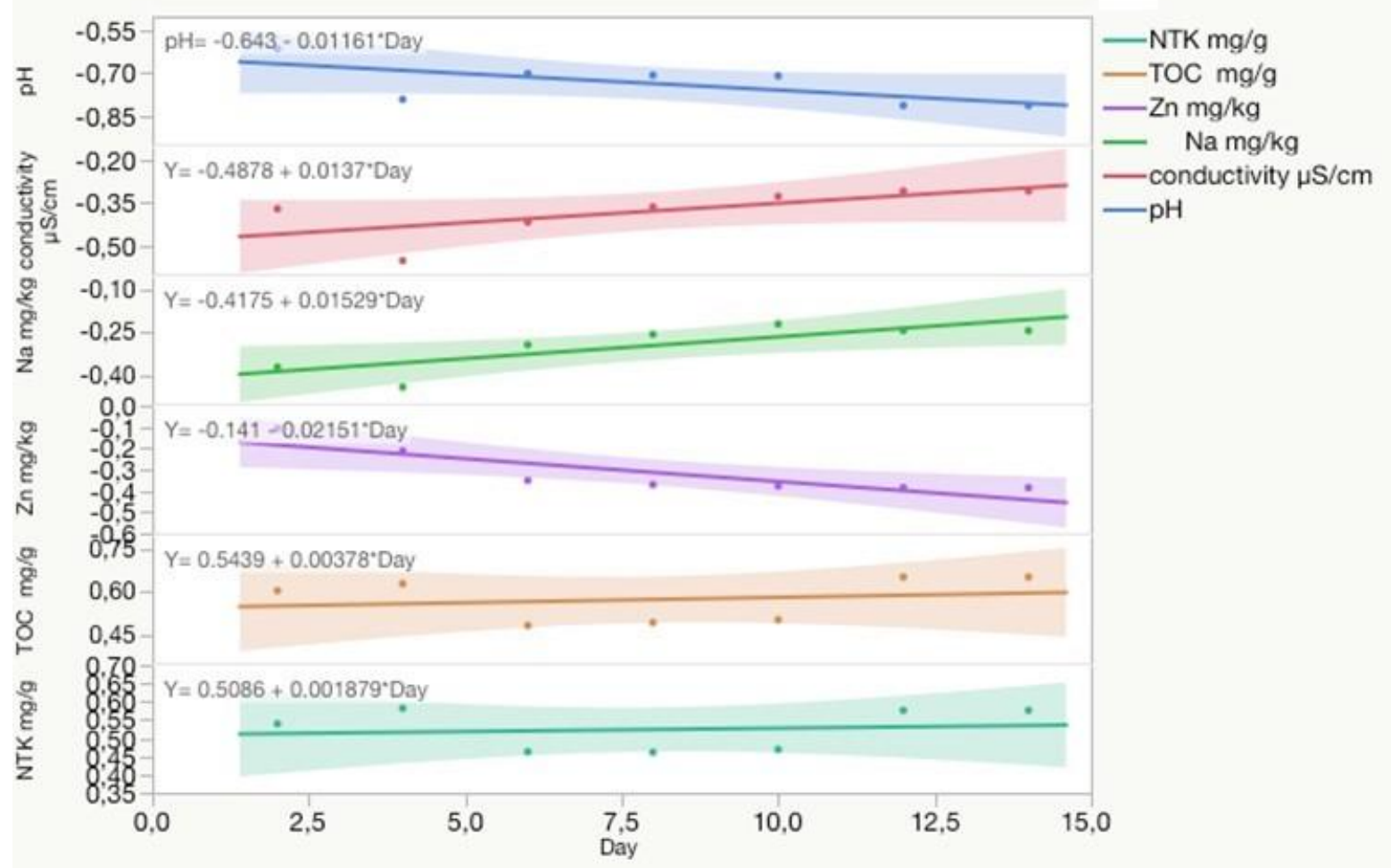

Supplementary data 3: Evolution of Spearman correlations between germination percentages and soil parameters up to 15 days after imbibition $(n=10, p \leq 0.05) . \rho X, Y$ : Spearman correlation, $X=G$ : germination percentage, $Y=p H, E C$, TOC, $(\mathrm{Na})$ : Na concentration, (Zn) Zn concentration.

The Line of Fit element shows a linear regression with confidence intervals in shady colors. 
Supplementary data 4: Bioaccumulation factor (BCF) and translocation factor (TF) values for each metal and metalloid in A. halimus growing on the different soil types.

\begin{tabular}{|c|c|c|c|c|c|c|c|c|c|}
\hline \multirow[t]{2}{*}{ Soil origin } & \multicolumn{9}{|c|}{ Elements } \\
\hline & As & $\mathbf{C u}$ & $\mathbf{F e}$ & $\mathbf{K}$ & $\begin{array}{l}\text { Mn } \\
\text { BCF }\end{array}$ & $\mathbf{N a}$ & $\mathbf{P b}$ & $\mathbf{S b}$ & $\mathbf{Z n}$ \\
\hline Control (CN) & $\begin{array}{c}0.25 \pm 0.02 \\
\mathrm{c}\end{array}$ & $1.22 \pm 0.05 b$ & $\begin{array}{c}0.37 \pm 0.01 \\
\mathrm{e}\end{array}$ & $9.11 \pm 0.58 \mathrm{a}$ & $0.48 \pm 0.01 \mathrm{c}$ & $1.74 \pm 0.08 \mathrm{e}$ & $0.17 \pm 0.03 b$ & $0.16 \pm 0.01 b$ & $0.78 \pm 0.03 b c$ \\
\hline $\begin{array}{l}\text { Calanque de } \\
\text { Saména (SA) }\end{array}$ & $\begin{array}{c}0.77 \pm 0.12 \\
b\end{array}$ & $1.03 \pm 0.06 \mathrm{bc}$ & $\begin{array}{c}0.53 \pm 0.04 \\
\mathrm{~d}\end{array}$ & $3.52 \pm 0.19 \mathrm{~d}$ & $0.47 \pm 0.04 \mathrm{c}$ & $\begin{array}{c}3.75 \pm 0.77 b c \\
d\end{array}$ & $0.51 \pm 0.05 b$ & $4.0 \pm 0.4 \mathrm{a}$ & $0.8 \pm 0.1 b c$ \\
\hline $\begin{array}{c}\text { Calanque des Trous } \\
\text { (TR) }\end{array}$ & $\begin{array}{c}0.120 \pm 0.0 \\
03 c\end{array}$ & $0.03 \pm 0.00 \mathrm{e}$ & $0.24 \pm 0.00 \mathrm{f}$ & $5.45 \pm 0.07 \mathrm{c}$ & $0.26 \pm 0.01 \mathrm{~d}$ & $5.79 \pm 0.52 \mathrm{a}$ & $0.02 \pm 0.00 \mathrm{~b}$ & $0.01 \pm 0.00 \mathrm{~b}$ & $0.02 \pm 0.00 \mathrm{e}$ \\
\hline Cap croisette (CC) & $1.2 \pm 0.1 \mathrm{a}$ & $1.72 \pm 0.15 \mathrm{a}$ & $\begin{array}{c}0.85 \pm 0.05 \\
\mathrm{~b}\end{array}$ & $3.31 \pm 0.16 \mathrm{~d}$ & $1.09 \pm 0.05 \mathrm{a}$ & $\begin{array}{c}4.81 \pm 0.57 \mathrm{ab} \\
\mathrm{c}\end{array}$ & $0.91 \pm 0.14 b$ & $0.25 \pm 0.02 b$ & $1.07 \pm 0.10 \mathrm{~b}$ \\
\hline E. Chimney (E.C) & $\begin{array}{c}1.39 \pm 0.09 \\
\mathrm{a}\end{array}$ & $0.88 \pm 0.03 \mathrm{c}$ & $\begin{array}{c}1.16 \pm 0.04 \\
\mathrm{a}\end{array}$ & $7.25 \pm 0.96 b$ & $0.59 \pm 0.04 b$ & $3.58 \pm 0.37 \mathrm{~cd}$ & $13.84 \pm 3.43 \mathrm{a}$ & $0.2 \pm 0.08 \mathrm{~b}$ & $1.43 \pm 0.23 \mathrm{a}$ \\
\hline E. Slagheap (E.S) & $\begin{array}{c}0.95 \pm 0.03 \\
b\end{array}$ & $0.39 \pm 0.03 \mathrm{~d}$ & $\begin{array}{c}0.65 \pm 0.01 \\
\mathrm{c}\end{array}$ & $9.33 \pm 0.08 \mathrm{a}$ & $\begin{array}{l}0.310 \pm 0.00 \\
2 \mathrm{~d}\end{array}$ & $2.56 \pm 0.21 \mathrm{de}$ & $0.44 \pm 0.02 b$ & $0.21 \pm 0.01 b$ & $0.40 \pm 0.03 \mathrm{~d}$ \\
\hline Sormiou (SO) & $\begin{array}{c}0.26 \pm 0.02 \\
\mathrm{c}\end{array}$ & $1.61 \pm 0.07 \mathrm{a}$ & $\begin{array}{c}0.55 \pm 0.02 \\
\mathrm{~d}\end{array}$ & $1.86 \pm 0.12 \mathrm{e}$ & $0.60 \pm 0.02 b$ & $\begin{array}{c}4.92 \pm 0.37 \mathrm{ab} \\
\mathrm{c}\end{array}$ & $0.32 \pm 0.03 b$ & $0.07 \pm 0.00 \mathrm{~b}$ & $0.75 \pm 0.05 \mathrm{c}$ \\
\hline & $062+005$ & & $012+002$ & & $\mathrm{TF}$ & & & & \\
\hline Control (CN) & $\begin{array}{c}0.0< \pm 0.05 \\
a\end{array}$ & $0.58 \pm 0.09 b$ & $\begin{array}{c}0.1 \angle \pm 0.02 \\
a\end{array}$ & $2.36 \pm 0.18 \mathrm{e}$ & $2.25 \pm 0.05 \mathrm{a}$ & $10.79 \pm 0.57 \mathrm{a}$ & $0.44 \pm 0.1 \mathrm{a}$ & $1 \pm 0 \mathrm{a}$ & $2.58 \pm 0.18 \mathrm{ab}$ \\
\hline $\begin{array}{l}\text { Calanque de } \\
\text { Saména (SA) }\end{array}$ & $\begin{array}{c}0.03 \pm 0.00 \\
\mathrm{c}\end{array}$ & $0.32 \pm 0.02 \mathrm{c}$ & $\begin{array}{l}0.03 \pm 0.00 \\
\text { ef }\end{array}$ & $2.5 \pm 0.11 \mathrm{de}$ & $0.11 \pm 0.01 \mathrm{~d}$ & $6.89 \pm 1.13 b c$ & $0.05 \pm 0 \mathrm{~b}$ & $0.06 \pm 0.00 \mathrm{~b}$ & $0.41 \pm 0.02 \mathrm{e}$ \\
\hline
\end{tabular}




\begin{tabular}{ccccccccccc}
$\begin{array}{c}\text { Calanque des Trous } \\
\text { (TR) }\end{array}$ & $\begin{array}{c}0.28 \pm 0.07 \\
\mathrm{~b}\end{array}$ & $0.29 \pm 0.02 \mathrm{c}$ & $\begin{array}{c}0.08 \pm 0.02 \\
\mathrm{bc}\end{array}$ & $3.24 \pm 0.17 \mathrm{~cd}$ & $0.24 \pm 0.02 \mathrm{bc}$ & $10.56 \pm 0.94 \mathrm{a}$ & $0.07 \pm 0.01 \mathrm{~b}$ & $0.06 \pm 0.00 \mathrm{~b}$ & $0.68 \pm 0.02 \mathrm{~d}$ \\
Cap croisette (CC) & $\begin{array}{c}0.17 \pm 0.00 \\
\mathrm{~b}\end{array}$ & $0.42 \pm 0.01 \mathrm{bc}$ & $\begin{array}{c}0.04 \pm 0.00 \\
\mathrm{de}\end{array}$ & $4.18 \pm 0.15 \mathrm{ab}$ & $0.23 \pm 0.00 \mathrm{bc}$ & $8.41 \pm 0.79 \mathrm{ab}$ & $0.15 \pm 0.01 \mathrm{~b}$ & $1 \pm 0 \mathrm{a}$ & $1.10 \pm 0.03 \mathrm{c}$ \\
E. Chimney (E.C) & $\begin{array}{c}0.03 \pm 0.00 \\
\mathrm{c}\end{array}$ & $0.38 \pm 0.04 \mathrm{c}$ & $\begin{array}{c}0.1 \pm 0.01 \mathrm{c} \\
\mathrm{d}\end{array}$ & $4.45 \pm 0.63 \mathrm{a}$ & $0.14 \pm 0.01 \mathrm{~cd}$ & $4.88 \pm 0.49 \mathrm{c}$ & $0.04 \pm 0.01 \mathrm{~b}$ & $0.05 \pm 0.01 \mathrm{c}$ & $0.23 \pm 0.02 \mathrm{ef}$ \\
E. Slagheap (E.S) & $\begin{array}{c}0.02 \pm 0.00 \\
\mathrm{c}\end{array}$ & $0.04 \pm 0.00 \mathrm{~d}$ & $0 \pm 0 \mathrm{f}$ & $3.46 \pm 0.09 \mathrm{bc}$ & $0.11 \pm 0.01 \mathrm{~d}$ & $5.62 \pm 0.52 \mathrm{bc}$ & $0 \pm 0 \mathrm{~b}$ & $0.02 \pm 0.00 \mathrm{~d}$ & $0.10 \pm 0.01 \mathrm{f}$ \\
Sormiou (SO) & $\begin{array}{c}0.14 \pm 0.01 \\
\mathrm{~b}\end{array}$ & $0.89 \pm 0.04 \mathrm{a}$ & $0.07 \pm 0 \mathrm{~cd}$ & $3.33 \pm 0.22 \mathrm{c}$ & $0.31 \pm 0.01 \mathrm{~b}$ & $4.67 \pm 0.36 \mathrm{c}$ & $0.39 \pm 0.05 \mathrm{a}$ & $1 \pm 0 \mathrm{a}$ & $1.91 \pm 0.11 \mathrm{~b}$ \\
\hline
\end{tabular}

Different letters following means \pm standard error $(\mathrm{SE})$ in a column indicate significant difference $(\mathrm{n}=3, \mathrm{p} \leq 0.05$, Wilcoxon test). 
Supplementary data 5: $\mathrm{Na} / \mathrm{K}$ ratio in different soil types, and in root and shoot of A. halimus growing on these different soils.

\begin{tabular}{llll}
\hline Soil origin & Soil Na/K & Root Na/K & Shoot Na/K \\
\hline Control (CN) & $0,5656 \pm 0,0008 \mathrm{a}$ & $0,109 \pm 0,004 \mathrm{c}$ & $0,51 \pm 0,03 \mathrm{~b}$ \\
Calanque de Saména (SA) & $0,42 \pm 0,02 \mathrm{c}$ & $0,42 \pm 0,05 \mathrm{a}$ & $1,03 \pm 0,04 \mathrm{a}$ \\
Calanque des Trous (TR) & $0,33 \pm 0,01 \mathrm{~d}$ & $0,35 \pm 0,05 \mathrm{a}$ & $1,09 \pm 0,08 \mathrm{a}$ \\
Cap croisette (CC) & $0,1741 \pm 0,0003 \mathrm{e}$ & $0,25 \pm 0,02 \mathrm{~b}$ & $0,470 \pm 0,003 \mathrm{~b}$ \\
E. Chimney (E.C) & $0,481 \pm 0,003 \mathrm{~b}$ & $0,25 \pm 0,01 \mathrm{~b}$ & $0,280 \pm 0,004 \mathrm{c}$ \\
E. Slagheap (E.S) & $0,329 \pm 0,002 \mathrm{~d}$ & $0,091 \pm 0,008 \mathrm{c}$ & $0,139 \pm 0,001 \mathrm{~d}$ \\
Sormiou (SO) & $0,056 \pm 0,0004 \mathrm{f}$ & $0,16 \pm 0,02 \mathrm{~b}$ & $0,207 \pm 0,003 \mathrm{~d}$ \\
\hline
\end{tabular}

Different letters following means \pm standard error $(\mathrm{SE})$ in a column indicate significant difference $(\mathrm{n}=3, \mathrm{p} \leq 0.05$, Wilcoxon test). 
Click here to download Interactive Map file (.kml or .kmz): GPS_data-0607073342.kml

(20)

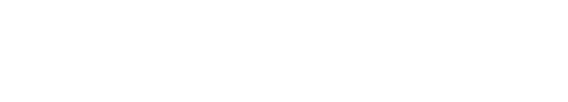

